Research Papers, part of a Special Feature on Bird Conservation in the Boreal Forest: Is there a Case for Resilience?

\title{
Forest Policy Scenario Analysis: Sensitivity of Songbird Community to Changes in Forest Cover Amount and Configuration
}

\section{Analyse de scénarios de politiques forestières : sensibilité de la communauté de passereaux aux changements dans la configuration et l'étendue du couvert forestier}

\author{
$\underline{\text { Robert S. Rempel }}^{1,2}{ }^{\text {Jim Baker }}{ }^{1}, \underline{\text { Phil C. Elkie }}^{1}$, Michael J. Gluck $^{1}$, Janet Jackson $^{1}$, \\ $\underline{\text { Robert S. Kushneriuk }}^{1}$, Tom Moore ${ }^{3}$, and Ajith H. Perera ${ }^{1}$
}

\begin{abstract}
Changes in mature forest cover amount, composition, and configuration can be of significant consequence to wildlife populations. The response of wildlife to forest patterns is of concern to forest managers because it lies at the heart of such competing approaches to forest planning as aggregated vs. dispersed harvest block layouts. In this study, we developed a species assessment framework to evaluate the outcomes of forest management scenarios on biodiversity conservation objectives. Scenarios were assessed in the context of a broad range of forest structures and patterns that would be expected to occur under natural disturbance and succession processes. Spatial habitat models were used to predict the effects of varying degrees of mature forest cover amount, composition, and configuration on habitat occupancy for a set of 13 focal songbird species. We used a spatially explicit harvest scheduling program to model forest management options and simulate future forest conditions resulting from alternative forest management scenarios, and used a process-based fire-simulation model to simulate future forest conditions resulting from natural wildfire disturbance. Spatial pattern signatures were derived for both habitat occupancy and forest conditions, and these were placed in the context of the simulated range of natural variation. Strategic policy analyses were set in the context of current Ontario forest management policies. This included use of sequential time-restricted harvest blocks (created for Woodland caribou (Rangifer tarandus) conservation) and delayed harvest areas (created for American marten (Martes americana atrata) conservation). This approach increased the realism of the analysis, but reduced the generality of interpretations. We found that forest management options that create linear strips of old forest deviate the most from simulated natural patterns, and had the greatest negative effects on habitat occupancy, whereas policy options that specify deferment and timing of harvest for large blocks helped ensure the stable presence of an intact mature forest matrix over time. The management scenario that focused on maintaining compositional targets best supported biodiversity objectives by providing the composition patterns required by the 13 focal species, but this scenario may be improved by adding some broad-scale spatial objectives to better maintain large blocks of interior forest habitat through time.
\end{abstract}

RÉSUMÉ. Les changements dans la configuration, la composition et l'étendue du couvert forestier des forêts matures peuvent avoir des conséquences importantes sur les populations fauniques. La réaction de la faune aux patrons forestiers préoccupe les aménagistes car elle est au cœur d'approches de planification forestière aussi divergentes que l'agglomération et la dispersion des parterres de coupe. Dans cette étude, nous avons développé un cadre d'évaluation des espèces afin de mesurer les effets de différents scénarios d'aménagement forestier sur des objectifs de conservation de la biodiversité. Les scénarios ont été évalués ${ }^{1}$ Ontario Ministry of Natural Resources, ${ }^{2}$ Lakehead University, ${ }^{3}$ Spatial
Planning Systems

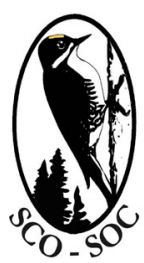

Sponsored by the Society of Canadian Ornithologists and Bird Studies Canada Parrainée par la Société des ornithologistes du Canada et Études d'oiseaux Canada

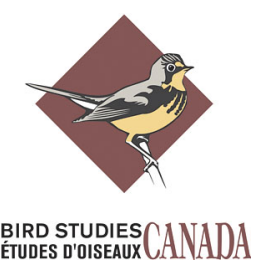


selon un large éventail de structures et de patrons forestiers susceptibles de se développer suite à des perturbations et à une succession naturelles. Des modèles d'utilisation de l'habitat spatialement explicites ont permis de prédire les effets du couvert, de la composition et de la configuration des forêts matures, à des degrés variables, sur l'occurrence de 13 espèces de passereaux spécialistes. Nous avons utilisé un programme de planification de la récolte spatialement explicite pour modéliser les options d'aménagement forestier et simuler les conditions futures des forêts qui résulteraient de divers scénarios d'aménagement. Nous avons aussi utilisé un modèle de simulation de feux basé sur les processus pour simuler les conditions futures des forêts qui subiraient de telles perturbations dans des conditions naturelles. Les signatures des patrons spatiaux ont été obtenues à la fois pour l'occurrence des oiseaux dans l'habitat et les conditions forestières, en simulant un éventail de variations naturelles. Les analyses des politiques stratégiques ont été effectuées dans le contexte des politiques d'aménagement forestier en vigueur en Ontario. Ainsi, nous avons considéré la récolte restreinte dans le temps de façon séquentielle (créée pour la sauvegarde du Caribou des bois [Rangifer tarandus]) et les aires de récolte dont le temps de révolution est allongé (qui visent à protéger la Martre d'Amérique [Martes americana atrata]). Cette approche a augmenté le réalisme des analyses, mais a réduit la généralité des interprétations. Nous avons trouvé, d'une part, que les aménagements forestiers qui créent des bandes linéaires de vieilles forêts divergeaient le plus des patrons naturels simulés, et qu'ils avaient les effets négatifs les plus importants sur l'occurrence des oiseaux. D'autre part, les aménagements forestiers qui spécifiaient l'étalement et le moment de la récolte de grands parterres de coupe ont contribué à assurer la présence constante d'une matrice de forêts matures intactes au fil du temps. Le scénario d'aménagement qui visait le maintien d'objectifs de composition est celui qui a atteint le mieux les objectifs de conservation de la biodiversité, car il a fourni les patrons de composition requis par les 13 espèces-cibles d'oiseaux. Ce scénario pourrait toutefois être amélioré par l'ajout d'objectifs spatiaux à grande échelle visant à mieux maintenir, dans le temps, de grands massifs continus de forêts.

Key Words: edge; forest management; habitat; landscape; multiple scale; resilience; RSF; RSPF; scenarios; songbird

\section{INTRODUCTION}

The effect of forest spatial pattern on wildlife habitat, and in particular, the amount, composition, and configuration of young and old forest, is of concern to forest managers because of its potential effect on biodiversity. In the boreal forest, conserving biodiversity requires maintaining habitat for species that prefer mature vs. young forest, hardwood vs. softwood forest, and various levels of mixing and interspersion of these forest types. Creating the right balance is difficult, and is one of the primary reasons that the natural disturbance paradigm has grown in popularity. A principal tenet of the paradigm is that biodiversity can be conserved by harvesting in a manner that resembles forest patterns created by natural disturbance processes (Hunter 1993, Bunnell 1995). Previous research has shown that some songbird species are resilient to changes in age-class and cover-type pattern, but only to a degree (Wedeles and Donnelly 2004, Parker et al. 2005, Schieck and Song 2006). The question of songbird resilience to forest management practices that decrease the amount of mature forest cover and change its configuration should be viewed from the perspective of the overall community response rather than the response of a few individual species. The pressing issue is how to create and assess the complex mixture of forest conditions that is expected to maintain the collective forest songbird community.

A principal argument against the natural disturbance approach is that we can never completely emulate natural disturbance, so we still must assign target levels and define the acceptable range of variability for key forest conditions. An alternative but complementary approach can be described in the following four steps. First, translate the range and dimensions of expected variability in natural disturbance patterns into a complementary model of variability in the dimensions of habitat nichespace (Fig. 1). Second, select an appropriate set of focal species that collectively are adapted to the range of niche-space applicable for the management 
area. Third, develop spatially explicit habitat models to define the complex arrangement of landscape pattern and habitat elements required by the focal group. Fourth, evaluate whether planned management targets support the full range of habitat needs, and whether the arrangement falls within the expected range of natural variation. This approach allows managers to determine more precisely the range of forest characteristics required to sustain the boreal forest songbird community. In a parallel study, steps 1-3 of this process were completed, and resulted in the selection of validated spatial habitat models for 13 focal species to assess biodiversity conservation options (Rempel 2007). Focal, rather than umbrella or other types of indicator species were used because of the value of establishing direct relationships between forest management options and species response (Hannon and McCallum 2004, Rempel et al. 2004), and the ability to define a broad niche-space based on species habitat associations (Fig. 1).

Linking quantitative habitat models to harvest scheduling models can be used to predict the future consequences of alternative forest management decisions on critical forest pattern and structure variables, and how this translates to predicted habitat occupancy patterns. Likewise, linking habitat and natural disturbance simulation models can be used to evaluate the degree to which projected future habitat conditions deviate from what is expected under a natural disturbance regime. However, a requirement of this approach is that managers must now select the appropriate suite of species for modeling habitat requirements. The natural variability or niche-space model (Fig. 1) can help guide the selection of those species.

Some studies have evaluated the effect of spatial harvest constraints on wildlife objectives (Liu et al. 2000, Baskent and Jordan 2002) and others have included non-spatial habitat models in the assessment of projected forests (Rempel and Kaufmann 2003). The model "Seles" (Fall and Fall 2001) has been used to evaluate combined effects of management and natural disturbance on age-class structure (Fall et al. 2004), and other studies have developed and applied spatial habitat models for the evaluation of projected forest conditions (e.g., Arthaud and Rose 1996, Mitchell et al. 2001, Calkin et al. 2002, Johnson et al. 2004, Loehle et al. 2006, Mitchell et al. 2006, Rempel et al. 2006). Only a few studies (e.g., van Damme et al. 2003) have placed spatial habitat evaluations in the context of variability expected under a natural disturbance regime and long-term forest management projections. Rempel et al. (2004) described a process to link proposed management actions to the selection of focal indicator species that are likely to respond to management actions, and Rempel et al. (2006) defined and applied a meta-modeling framework for a management-driven songbird study in Manitoba, Canada, that links various modeling components (including spatial habitat models) for conducting landscape-scale assessments of biodiversity strategies.

Here, we further develop this approach by placing modeling scenario results in the context of both policy options and the simulated range of natural variation. The objective of this study is to (1) use the harvest schedule model "Patchworks" (Lockwood and Moore 1993, Baskent and Keles 2005) and associated stand structure and succession curves to project future forest conditions under alternative management strategies that vary the degree of mature forest cover amount and configuration, (2) apply validated spatial habitat models to assess projected future forests, (3) use a newly developed spatial modeling language "LSL" (Kushneriuk and Rempel 2004) to evaluate alternative forest management policy options in terms of sustaining songbird communities, and (4) compare and contrast modeling results with expectations under a simulated natural disturbance regime generated by the Boreal Forest Landscape Dynamics Simulator (BFOLDS) (Perera et al. 2004).

\section{METHODS}

\section{Meta-model}

The scenario analysis framework can be viewed as a linked set of models that includes habitat, wood supply, yield curve, harvest scheduling, spatial landscape assessment, stand structure, stand succession, and natural disturbance modeling components. We termed the overall framework a spatial landscape assessment meta-model (Fig. 2). The meta-model visually depicts links between data and modeling components described below. 
Fig. 1. Translation of variability in extent, intensity, and frequency of natural disturbance to habitat niche-space dimensions of patch interspersion, overstory composition, and stand structure.

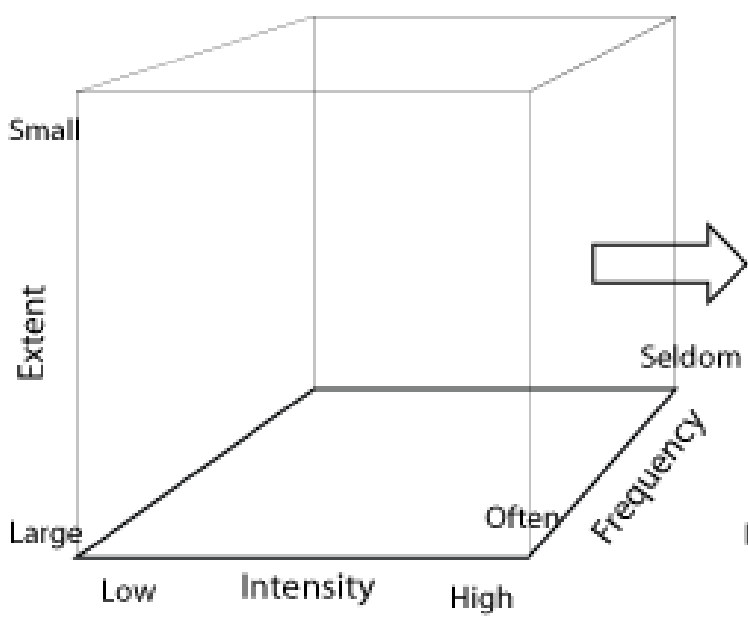

Natural Disturbance Variability

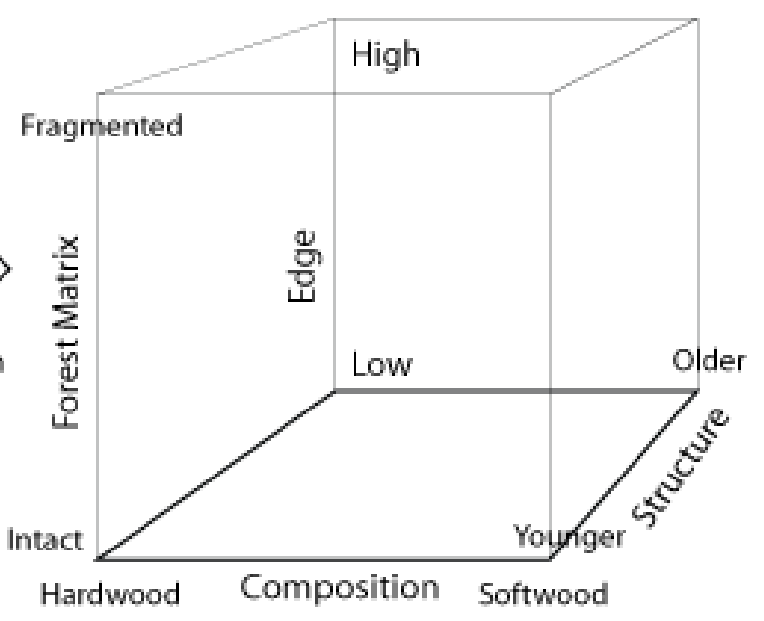

Habitat Niche Space

\section{Habitat Models}

We used spatially explicit, multiple-scale habitat models to predict the relationship between localscale (50 ha) and landscape-scale (5000 ha) forest variables (Table 1) and the probability of habitat occupancy for a focal set of 13 forest songbird species. Models were developed and tested in a related study using three locations in the northern boreal region of Ontario (Rempel 2007). Rinker Lake (RL), on the west side of Lake Nipigon, and the Nipigon Forest (NF) on the east side of Lake Nipigon are in dry-humid boreal conditions, and the Cochrane Study Area (CSA), which includes the northern part of the Claybelt region, is located in medium-humid boreal conditions (Fig. 3). All areas are located in forest management units with active logging. Models were developed using logistic regression, and the cut-point to classify a site as occupied/unoccupied was set to balance the probability of making false-positive vs. falsenegative errors (Rempel 2007). In scenario analysis figures, the term "high probability of habitat occupancy" refers to sites with probabilities of habitat occupancy above this critical threshold. All habitat models had a discrimination index (ROC value) $>0.65$, indicating a fair-to-good ability to, on average, assign higher probability of habitat occupancy to occupied sites and vice versa (Fig. 4). Species selected for scenario analysis represent a broad array of habitat associations, or niche-space (Fig. 1), and include species that are apparently resilient and non-resilient to landscape-scale patterns of contrast weighted edge-density (EDGE) and percent intact mature and old forest (INTACT). To meet the scenario analysis objectives of this study, it was critical to select species that occupied as many "corners of the box" (Fig. 1) as possible. Although the preferred minimum level of model discrimination was 0.70 for selecting the focal species, the niche-space requirements were critical, and this resulted in the selection of some species models with only fair discrimination and calibration levels (Rempel 2007). 
Fig. 2. Schematic diagram (meta-model) of links between model components, flow of data, and model outputs. Upper figure describes habitat modeling components, and lower figure describes scenario analysis components.

\section{Spatial Landscape Assessment Meta-Model}

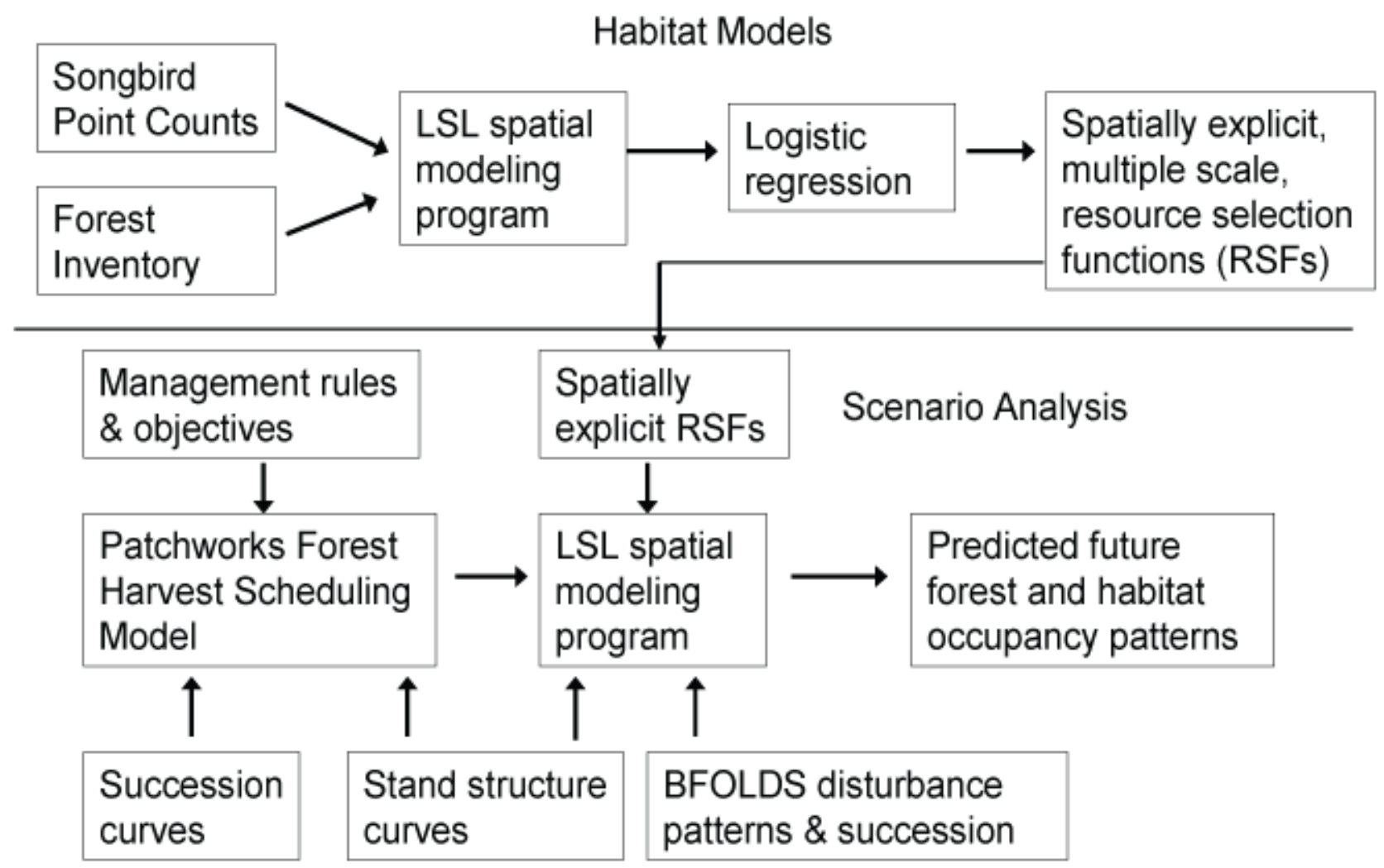

\section{Spatial Forest Projection}

Alternative forest management scenarios were simulated using Patchworks, a harvest scheduling program that generates forest harvest solutions in the context of vegetation succession, stand development, and forest management constraints (Lockwood and Moore 1993, Baskent and Keles 2005). Three management scenarios were simulated: (1 forest management under non-spatial guidelines (NOSPATIAL) only, such as silvicultural guidance for replanting, tending, and harvest volume objectives; (2) silvicultural guidelines plus all featured value guidelines (ALLGUIDES) as specified in Ontario's natural pattern emulation (NPE), timber management guidelines for marten (Martes americana atrata), moose (Alces alces), caribou (Rangifer tarandus), and fish habitat 
Table 1. Description of variables (and keywords) used in the habitat models. All variables calculated using hexagonal analysis units generated in LSL.

\begin{tabular}{|c|c|c|}
\hline Variable & Scale & Acronym \\
\hline Tree height & Local & HEIGHT \\
\hline $\begin{array}{l}\text { Percent hardwood } \\
\text { volume }\end{array}$ & Local & HARDWO \\
\hline Percent canopy closure & Local & CANOPY \\
\hline Average Stand Age & Local & AGE \\
\hline Percent Young Forest & Local & YOUNG \\
\hline $\begin{array}{l}\text { Contrast Weighted } \\
\text { Edge Density }\end{array}$ & Landscape & EDGE \\
\hline
\end{tabular}

Description

\begin{tabular}{|c|c|c|c|}
\hline Tree height & Local & HEIGHT & $\begin{array}{l}\text { Weighted average of Ontario forest resource inventory } \\
\text { (FRI) height, as measured from aerial photography using } \\
\text { a parallax bar. }\end{array}$ \\
\hline
\end{tabular}

Percent hardwood HARDWOOD

Edge Density

Percent Mature and Old Landscape Forest
INTACT

\begin{abstract}
A measure of cover type. Percentage of total merchantable timber that is hardwood. Interpolated from yield curves for standard forest units. Low levels indicate softwood cover type, high levels hardwood cover type.
\end{abstract}

Interpolated from FRI stand age.

Weighted average of FRI stand age. Interpretation based on stand height and texture.

A measure of young forest cover amount. Percentage of total forest $<20$ years.

A measure of forest cover configuration. Contrast weighted density of edge between young $(<20$ years old), immature, and mature ( $>60)$ forest, where young/ mature forest has a contrast weight of 1 , and immature a weight of 0.5 .

A measure of intact mature forest cover amount. Percentage of total forest $>80$ years old.
(Ontario Ministry of Natural Resources (OMNR) 1988a, 1988b, 1996, 2002, Racey et al. 1999), and (3) silvicultural guides plus natural composition targets (NATURAL) based on previous natural disturbance BFOLDS simulations (Table 2). The current state of the forest (CURRENT) represents a mix of natural disturbance events, gap dynamics, and timber management guidelines that have been applied over the last 60 or so years in the NF Management Unit. Only the ALLGUIDES scenario had spatial and temporal constraints to logging (caribou blocks, marten cores, and NPE old-growth and spatial targets), and these affect broad patterns of harvest eligibility (Fig. 5). Based on initial exploratory analysis of scenarios, NOSPATIAL, ALLGUIDES, and NATURAL scenarios were all set to achieve $100 \%$ of harvest using harvest patches of 100-1000 ha (where a patch is a clump of touching harvest blocks) to reduce unrealistically high levels of age-class fragmentation across the landscape.

Habitat element curves were developed to project changes in tree height and percent canopy closure over time (Fig. 6), and were based on analysis of Ontario growth and yield data (Elkie et al. 2004). Curves were created by fitting second-order polynomial equations to the data, and each plot was reviewed and in some cases revised using expert opinion to create the final plots and look-up tables. Separate look-up tables were created for upland conifer, lowland conifer, deciduous, deciduous mixedwood, Great Lakes-St. Lawrence pines, and conifer mixedwood. 
Fig. 3. Location of Rinker Lake, Nipigon Forest, and Cochrane Study Area study sites. Ecoregions based on Hills (1961), where 5S, 4S, and $3 \mathrm{~S}$ are sub-humid, $4 \mathrm{~W}$ and $3 \mathrm{~W}$ are dry-humid, and $3 \mathrm{E}$ and $2 \mathrm{E}$ are medium-humid.

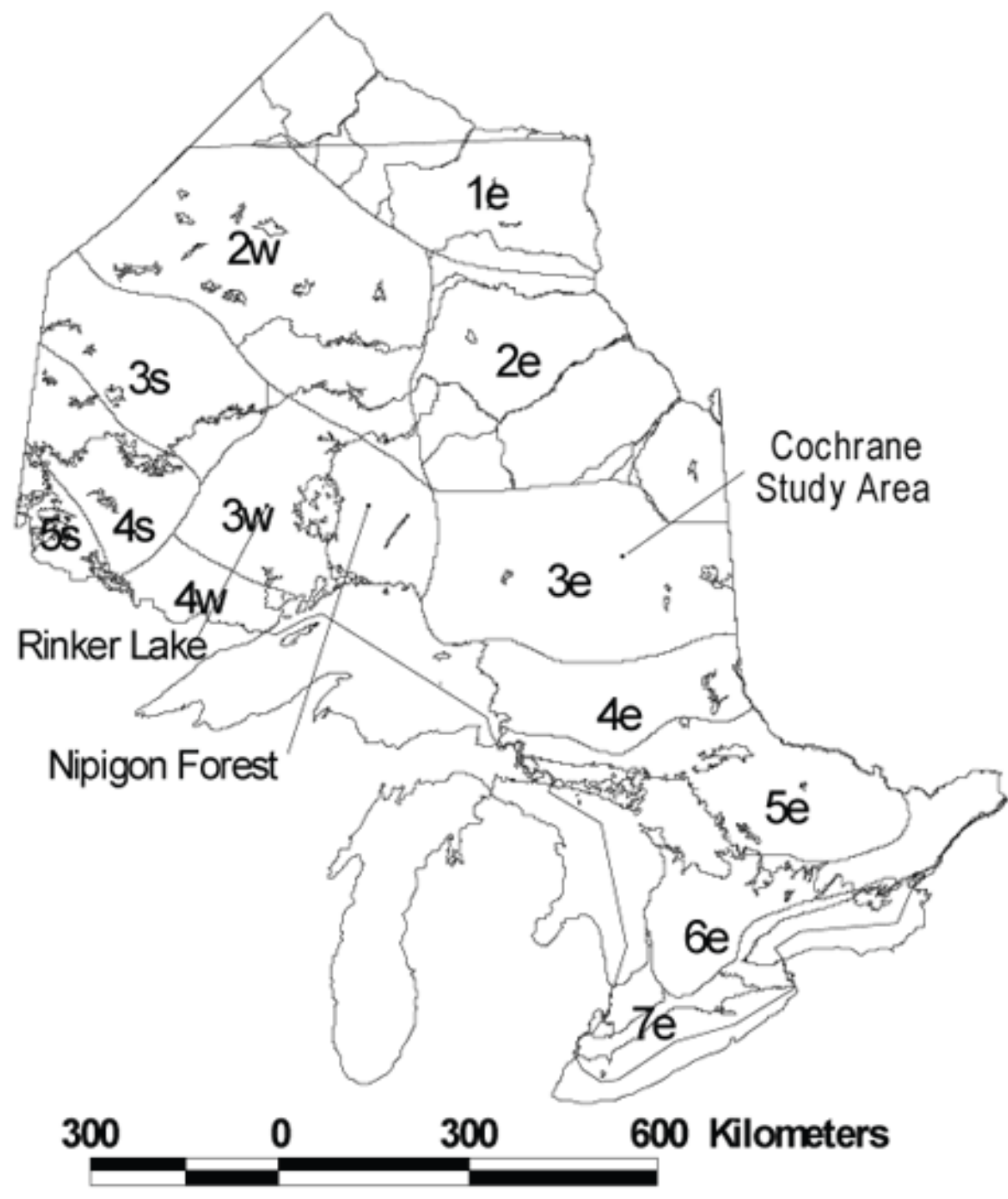


Fig. 4. Accuracy assessment (ROC) and 95\% confidence limits for the focal species habitat models. Values are area under the ROC curve, and represent the probability of correctly assigning the correct label (occupied/unoccupied) for new observations. Closed symbols are for model development (training), and open symbols for independent testing of the models.

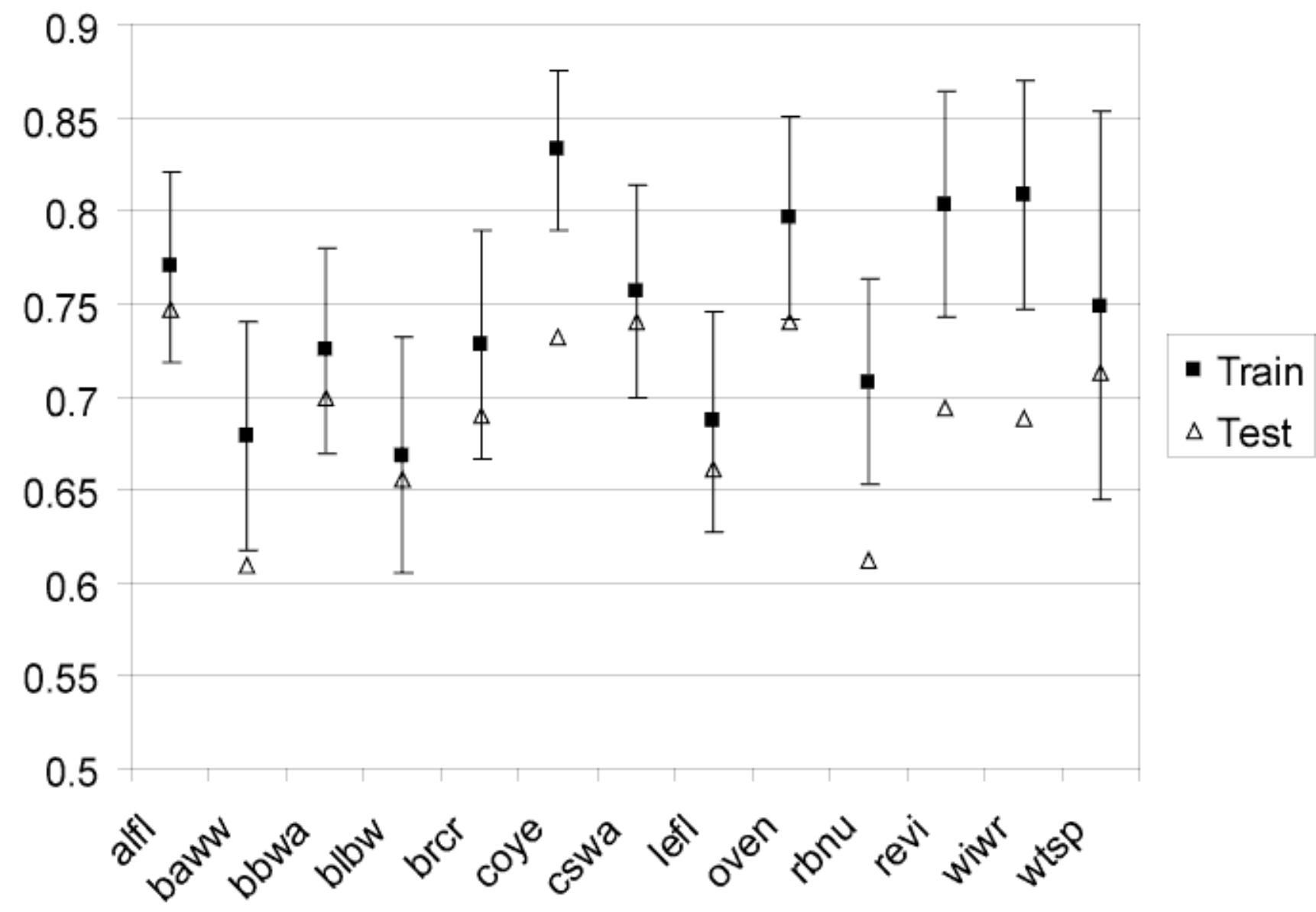

\section{Spatial Pattern Analysis and Simulated Range of Natural Variation}

Spatial environmental and species response data were captured using the recently developed spatial analysis programming language, LSL (Kushneriuk and Rempel 2004). A hexagonal grid of 7-ha cells was used to build a nested set of pseudo-hexagons, or gridsets, of increasingly larger size. A 5000-ha gridset was selected for the broadest scale of analysis (landscape scale), and 50 ha for the local scale. At 5000 ha, the linear distance from the center of the hexagon to the edge is between 3.5 and $4 \mathrm{~km}$, corresponding to the approximate range (linear distance) of spatial auto-correlation among songbird point counts (approx. $5 \mathrm{~km}$ ) (Rempel 2007). The 50-ha scale corresponds to the approximate area surveyed by a cluster of songbird point listening stations (maximum $150 \mathrm{~m}$ listening range).

Natural disturbance, and the associated range of variation, was simulated using BFOLDS (Perera et al. 2004), which is a process-based model, where 
Table 2. Description of the four conditions (current forest and three management scenarios) used in the scenario analysis.

\begin{tabular}{lll}
\hline \hline Scenario & Keyword & Description \\
\hline $\begin{array}{l}\text { Current State of the Forest } \\
\text { (year 2001) }\end{array}$ & CURRENT & Current state of the forest based on latest FRI. \\
No Spatial Guidelines & NOSPATIAL & $\begin{array}{l}\text { Basic silvicultural policies and practices are simulated along with a } \\
\text { realistic transportation budget and operational rules (e.g., winter harvest } \\
\text { areas), but no spatial harvest pattern objectives are defined. Harvest } \\
\text { volume targets based on existing supply commitments. }\end{array}$
\end{tabular}

All Featured Values $\quad$ ALLGUIDES Guidelines

Natural Composition Targets NATURAL

\begin{abstract}
NOSPATIAL silvicultural parameters, plus spatial pattern objectives based on guides for featured species (marten and caribou), the fish habitat guides, and non-spatial old-growth targets and harvest pattern from NDPEG. Harvest volume targets based on existing supply commitments.
\end{abstract}

Landscape Mosaic Scenario. Compositional targets set to emulate natural disturbance patterns and composition. The first set of objectives was derived from an analysis of BFOLDS runs for the entire ecoregion $3 \mathrm{~W}$. Minimum amounts of mature forest pattern class were used in a quasi-spatial strategic forest management model (SFMM). The strategic solution for the ecoregion was to harvest the Lake Nipigon Forest more aggressively than the current available harvest area (AHA; while reducing harvest levels on other FMUs below current AHAs). We used the resulting composition of the SFMM solution on Lake Nipigon as the objectives. Harvest volume targets were allowed to fluctuate through time. model components such as ignition and fire-spread rates are based on previously published research findings. The model creates simulated maps of future forest conditions expected under a natural disturbance regime. For each map, a histogram of the simulated variable was created (Fig. 7). The simulation was repeated 72 times (three burn intensities and eight replications for simulation years 100,150 , and 200) to generate $25^{\text {th }}$ and $75^{\text {th }}$ percentiles for each histogram bar. This simulated range of natural variation (SRNV) is denoted on the histograms by upper and lower "*". The interquartile range, rather than standard deviation, was used to characterize dispersion because of its robustness to outliers and non-normal distributions in the data. Note that the class intervals for the chart's $\mathrm{x}$-axis are also based on the average $25^{\text {th }}$, $50^{\text {th }}$, and $75^{\text {th }}$ percentiles (in area) for the simulated data, so a coarse bell-shaped pattern will be expected for the SRNV values. The RSPF models were also applied to BFOLDS simulations to create SRNV values for habitat occupancy classes.

\section{RESULTS}

\section{Habitat Model Characteristics}

The spatial habitat models for the 13 focal species were applied to the current forest resource inventory (FRI) maps, and mean values for model forest variables were summarized for areas of high probability of habitat occupancy vs. low probability (Table 3). These emergent averages summarize the typical forest conditions that the habitat models predict would be associated with the best habitat. For example, the model predicts that Alder Flycatcher (Empidonax alnorum) will be associated with a $13.9 \%$ decrease in CANOPY, a $4.1 \mathrm{~m}$ 
Fig. 5. Sequential timings (years from present) for when blocks are available for harvest (Caribou Blocks), and for when reserve blocks are unavailable for harvest (Marten Core Areas) in the Lake Nipigon forest management unit. These timings are used in both the existing spatial harvest guidelines.

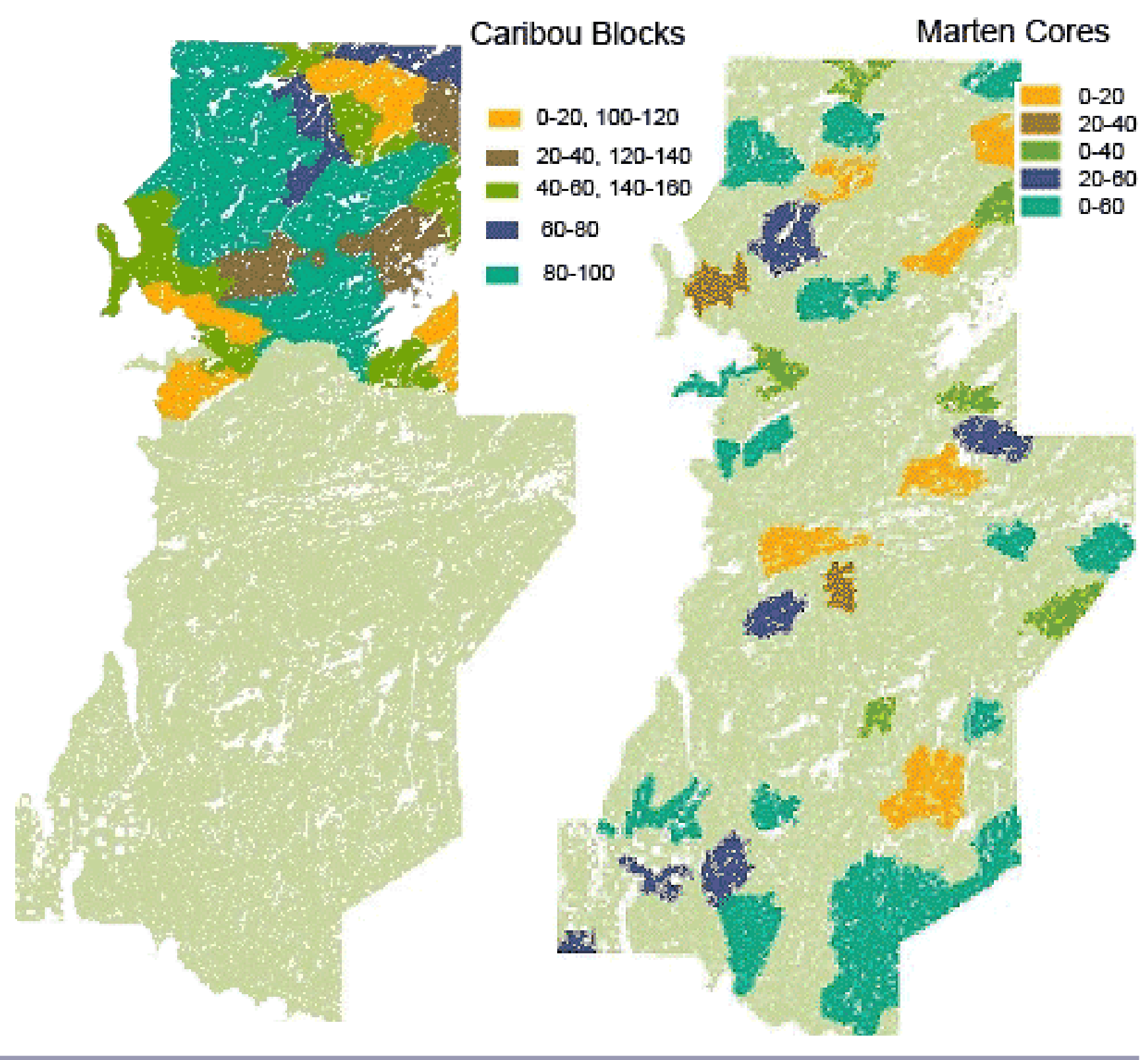


Fig. 6. Habitat element curves (HECs) for percent canopy closure and tree height $(\mathrm{m})$ for northern upland conifer (NUC), northern lowland conifer (NLC), northern conifer mixed (NCM), northern deciduous (ND), and northern deciduous mixed (NDM).
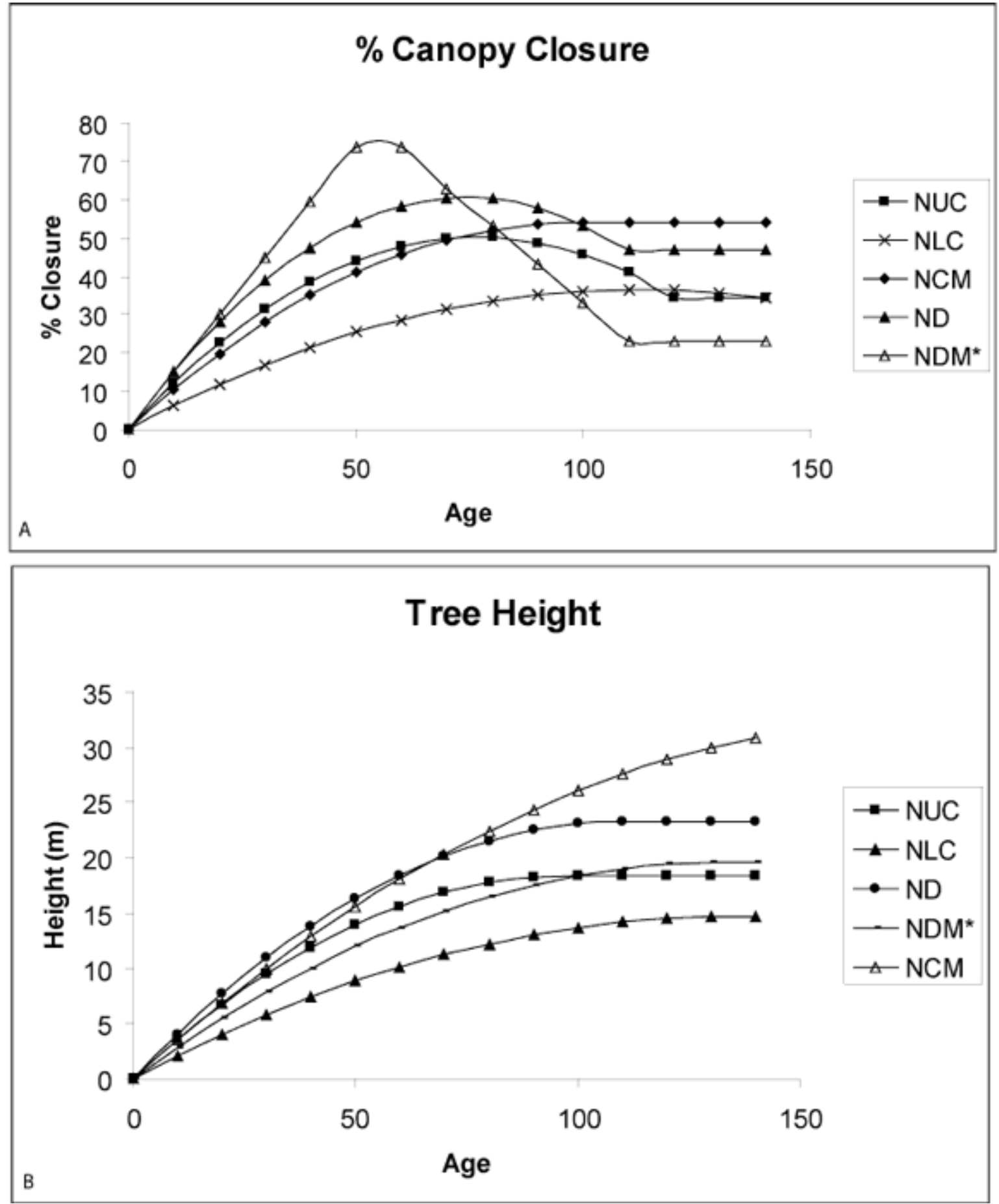
Fig. 7. Development and application of simulated range of natural variation (SRNV), and spatial pattern signatures: (A) 1 of 72 natural disturbance simulation maps (using BFOLDS) for ecoregion $3 \mathrm{~W}$, (B) projected map of EDGE (using Patchworks) for Nipigon Forest under the no spatial guides

(NOSPATIAL) management scenario, (C) proportion of map-area with low, medium, and high contrast weighted edge density (EDGE), where asterisks are 25th and 75th percentiles for histogram heights among all 72 replications for ecoregion 3W, (D) proportion of Nipigon Forest map-area with low, medium, and high EDGE, among four scenarios, and where asterisks represent SRNV for EDGE from (C) above.
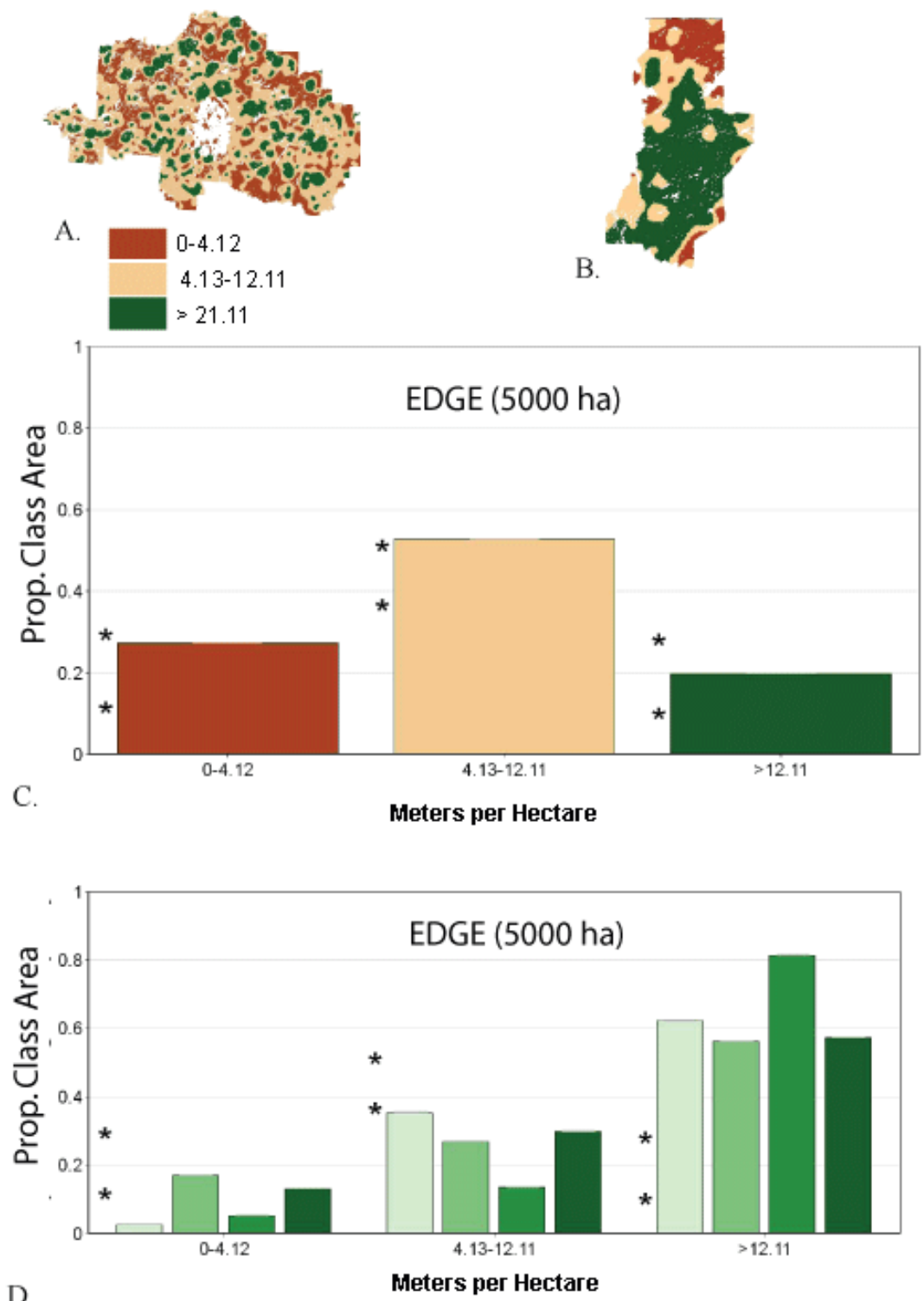
decrease in average HEIGHT, a $17 \%$ increase in HARDWOOD, and a $9.9 \mathrm{~m} / \mathrm{ha}$ increase in EDGE. Overall, the 13 models characterize a broad range of habitat conditions at the local and landscape scale that would likely be associated with a natural and diverse forest region. The models can be grouped into five rough categories:

Younger, more open hardwood forest, with high disturbance and edge levels: Alder Flycatcher, Black-and-white Warbler (Mniotilta varia), Chestnut-sided Warbler (Dendroica pennsylvanica), Common Yellowthroat (Geothlypis trichas).

Older softwood mixedwood, lower edge, higher intact forest: Bay-breasted Warbler (Dendroica castanea), Blackburnian Warbler (Dendroica fusca), Brown Creeper (Certhia americana), Redbreasted Nuthatch (Sitta canadensis), Winter Wren (Troglodytes troglodytes).

Older, open mixedwood, more intact forest: Whitethroated Sparrow (Zonotrichia albicollis).

Closed hardwood, more disturbance, less intact forest: Red-eyed Vireo (Vireo olivaceous), Least Flycatcher (Empidonax minimus).

Closed hardwood, less disturbance and edge, less intact forest: Ovenbird (Seiurus aurocapillus).

In general, the models agree with common field observations and understanding of habitat associations, especially at the local scale (Rempel 2007). One exception may be the Least Flycatcher, where some studies suggest this is more of a forest interior species. Nonetheless, this species was associated with younger (but closed) hardwoods in all three study areas.

\section{Forest Variables}

The percentage of hardwoods in the current forest is higher than expected under SRNV, whereas the three management alternatives bring the level of hardwoods closer to that expected under SRNV (Fig. 8). Perhaps hardwood levels are currently elevated because of harvest selection for softwoods, or because of failed softwood regeneration efforts. In contrast, the modeled management scenarios all assume perfect regeneration success, and this is probably unrealistic.
Maintaining an intact mature forest matrix will be necessary to create habitat for interior forest species, and the forest and management projections based on all featured value management practices have elevated levels of partially fragmented forest matrix. Intermediate levels of intact forest (23.5$76.3 \%$ ) were higher in both CURRENT and ALLGUIDES relative to SRNV (Fig. 9). In contrast, intact forest matrix is relatively similar to SRNV for both the scenario that provides no landscape-scale spatial direction (NOSPATIAL) and the scenario that prescribes natural composition targets (NATURAL).

At year 100, edge was higher than expected in both the current forest and all three management scenarios. For example, the density of edge between young and old forest is higher than SRNV for all four conditions, but the levels for the highest edge grouping $(>12 \mathrm{~m} / \mathrm{ha})$ is considerably higher for the ALLGUIDES scenario (Fig. 10). Note, however, that much of the northern part of the Nipigon forest management unit (FMU) became available for harvest in years 80-100 because of caribou-block timings (Fig. 4), so the high values of edge in year 100 are a result of the previous 20 years of harvest, and this value should decrease in the subsequent 50 years.

Scoring the scenarios is based on objectives of the management plan or on policy goals. In this case, the objective is to produce guidelines that will conserve biodiversity through emulation of natural patterns. Consequently, a scenario that causes a forest variable to either increase or decrease from the expected SRNV range was given a -1 score, and those that stayed within the SRNV range were given a score of 1 (Table 4). Overall, at year 100, the scenarios NOSPATIAL and NATURAL produced stand structures and landscape patterns that better stayed within the range of variation for simulated natural patterns. These two scenarios maintained pattern signatures within the bounds of SRNV for the four variables HARDWOOD, CANOPY, AGE, and INTACT, whereas CURRENT and ALLGUIDES maintained pattern signatures within the bounds of SRNV for only one and two variables, respectively (Table 4). Only NOSPATIAL and NATURAL maintained a landscape-scale variable within the bounds of SRNV. Maps and histograms for all model variables (ALLGUIDES and NATURAL) scenarios, over years $0,10,20,50,100$, and 150 , are given in Appendices 1 and 2. 
Table 3. Difference in habitat variable averages for high vs. low probability of habitat occupancy, when the habitat models are applied to the current forest inventory.

\begin{tabular}{|c|c|c|c|c|c|c|c|c|c|}
\hline \multirow{2}{*}{$\begin{array}{l}\text { Common } \\
\text { name }\end{array}$} & \multirow[t]{2}{*}{ AOU code } & \multirow[t]{2}{*}{ Latin name } & \multirow[t]{2}{*}{ CANOPY } & \multirow[t]{2}{*}{ HEIGHT } & \multicolumn{3}{|c|}{ Local } & \multicolumn{2}{|c|}{ Landscape } \\
\hline & & & & & YOUNG & AGE & HWD & EDGE & INTACT \\
\hline $\begin{array}{l}\text { Alder Flyc- } \\
\text { atcher } \dagger\end{array}$ & ALFL & $\begin{array}{l}\text { Empidonax } \\
\text { alnorum }\end{array}$ & -13.9 & -4.1 & 0.24 & -10.1 & -0.17 & 9.9 & -0.01 \\
\hline $\begin{array}{l}\text { Black-and- } \\
\text { white Warbler }\end{array}$ & BAWW & $\begin{array}{l}\text { Mniotilta } \\
\text { varia }\end{array}$ & -2.4 & -3.2 & 0.04 & -31.7 & 0.14 & 1.2 & -0.52 \\
\hline $\begin{array}{l}\text { Bay-breasted } \\
\text { Warbler }\end{array}$ & BBWA & $\begin{array}{l}\text { Dendroica } \\
\text { castanea }\end{array}$ & 0.2 & 0.2 & -0.16 & 15.5 & -0.16 & -5.1 & 0.17 \\
\hline $\begin{array}{l}\text { Blackburnian } \\
\text { Warbler }\end{array}$ & BLBW & $\begin{array}{l}\text { Dendroica } \\
\text { fusca }\end{array}$ & 8.1 & 4.6 & -0.17 & 34.6 & 0.01 & -4.9 & 0.47 \\
\hline $\begin{array}{l}\text { Brown Cre- } \\
\text { eper }\end{array}$ & BRCR & $\begin{array}{l}\text { Certhia am- } \\
\text { ericana }\end{array}$ & 7.9 & 4.6 & -0.07 & 13.7 & 0.13 & -4.2 & 0.29 \\
\hline $\begin{array}{l}\text { Common } \\
\text { Yellowthroat }\end{array}$ & COYE & $\begin{array}{l}\text { Geothlypis } \\
\text { trichas }\end{array}$ & -15.7 & -4.9 & 0.31 & -16.8 & -0.13 & 8.4 & -0.10 \\
\hline $\begin{array}{l}\text { Chestnut- } \\
\text { sided Warbler }\end{array}$ & CSWA & $\begin{array}{l}\text { Dendroica } \\
\text { pensylvanica }\end{array}$ & -7.1 & -1.7 & 0.19 & -17.9 & 0.09 & 5.6 & -0.11 \\
\hline $\begin{array}{l}\text { Least Flyca- } \\
\text { tcher }\end{array}$ & LEFL & $\begin{array}{l}\text { Empidonax } \\
\text { minimus }\end{array}$ & 3.3 & -0.7 & -0.03 & -25.6 & 0.27 & -1.1 & -0.42 \\
\hline Ovenbird & OVEN & $\begin{array}{l}\text { Seiurus au- } \\
\text { rocapilla }\end{array}$ & 5.9 & 0.6 & -0.13 & -9.8 & 0.19 & -6.1 & -0.20 \\
\hline $\begin{array}{l}\text { Red-breasted } \\
\text { Nuthatch }\end{array}$ & RBNU & $\begin{array}{l}\text { Sitta canad- } \\
\text { ensis }\end{array}$ & 6.5 & 3.6 & -0.10 & 25.1 & -0.03 & -6.7 & 0.46 \\
\hline $\begin{array}{l}\text { Red-eyed } \\
\text { Vireo }\end{array}$ & REVI & $\begin{array}{l}\text { Vireo oliva- } \\
\text { ceus }\end{array}$ & 5.0 & 0.1 & -0.08 & -19.7 & 0.30 & -0.2 & -0.33 \\
\hline Winter Wren & WIWR & $\begin{array}{l}\text { Troglodytes } \\
\text { troglodytes }\end{array}$ & 0.7 & 2.3 & -0.05 & 32.3 & -0.16 & -1.4 & 0.52 \\
\hline $\begin{array}{l}\text { White-thro- } \\
\text { ated Sparrow }\end{array}$ & WTSP & $\begin{array}{l}\text { Zonotrichia } \\
\text { albicollis }\end{array}$ & -4.2 & 0.7 & 0.08 & 23.2 & -0.20 & 2.3 & 0.48 \\
\hline
\end{tabular}

$\dagger$. Values are relative to areas of high vs. low habitat quality. For example, the CANOPY value indicates a $13.9 \%$ decrease in canopy closure, and the HEIGHT value a $4.1 \mathrm{~m}$ decrease in tree height, in areas of the Nipigon Forest that are predicted to have high probability of Alder Flycatcher habitat occupancy, relative to areas of predicted low probability. 
Fig. 8. Spatial pattern signatures for percent hardwood volume (HARDWOOD) based on Patchworks projections (year 100) of four management scenarios (see Table 2 for definitions). Histograms depict proportion of map-area for low, medium, and high HARDWOOD for each of the four scenarios, and asterisks represent SRNV for HARDWOOD. Proportions are treated as percentages for discussion.
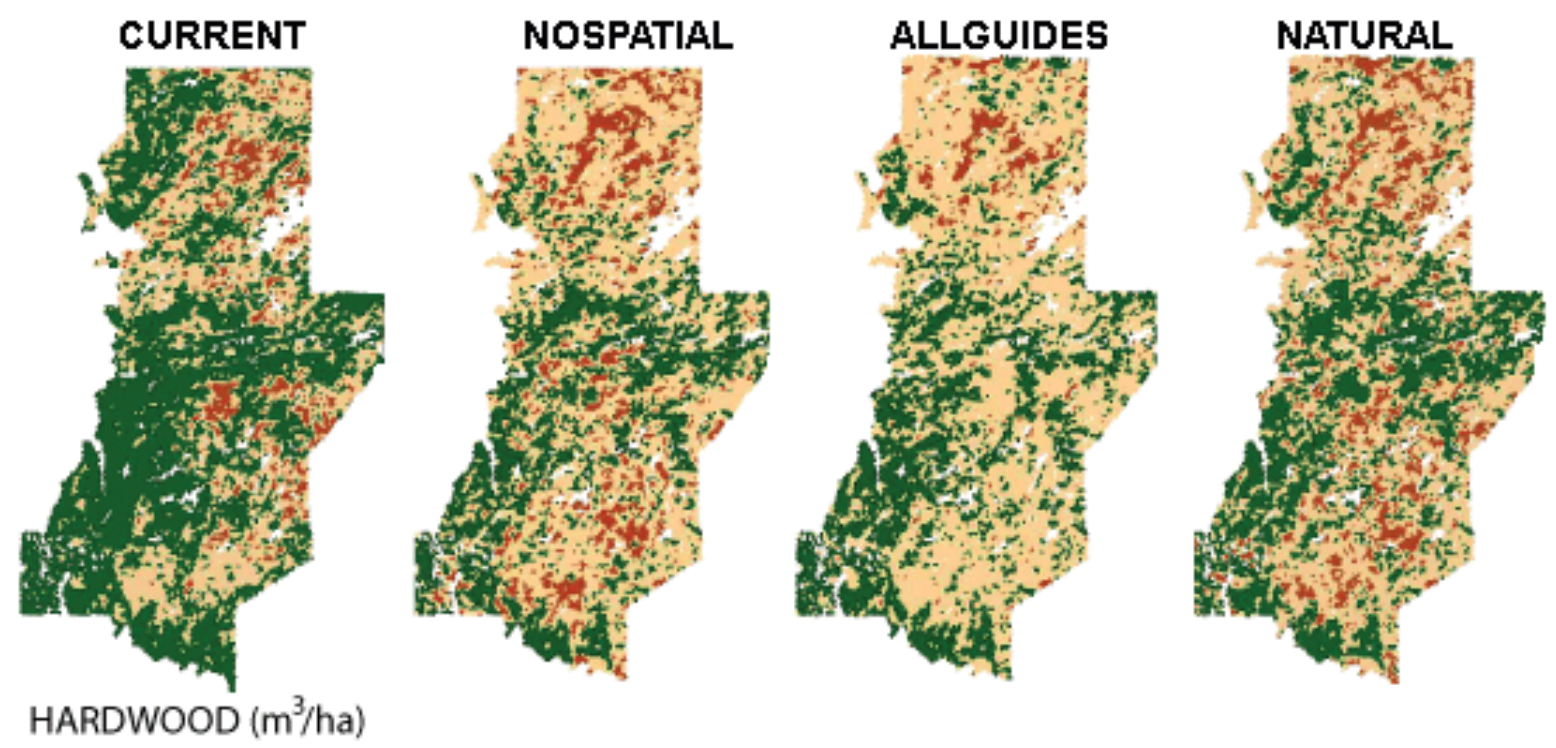

$0-0.045$

$0.046-0.235$

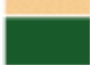

$>0.235$

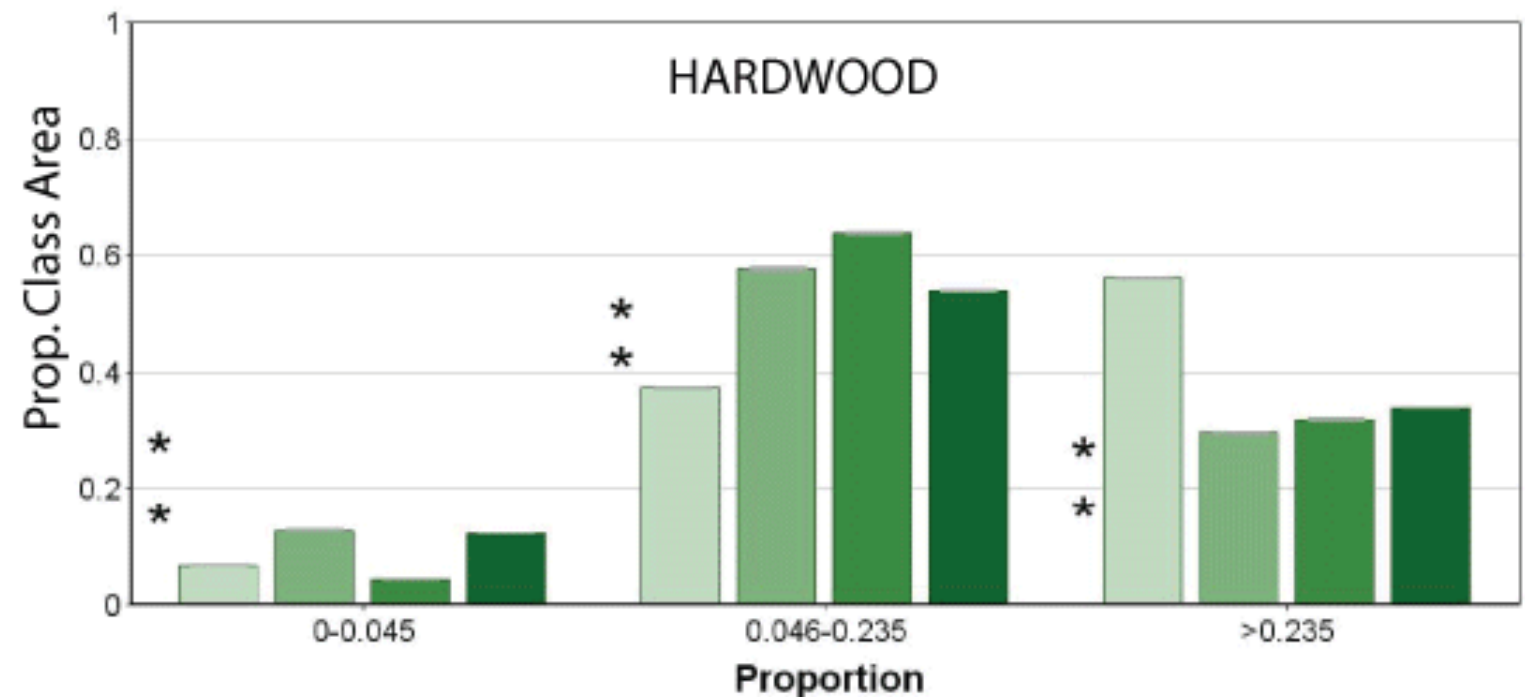

Left to right: CURRENT, NOSPATIAL, ALLGUIDES, NATURAL 
Fig. 9. Spatial pattern signatures for percent mature and old forest (INTACT) based on Patchworks projections (year 100) of four management scenarios (see Table 2 for definitions). Histograms depict proportion of map-area for low, medium, and high INTACT for each of the four scenarios, and asterisks represent SRNV for INTACT. Proportions are treated as percentages for discussion.
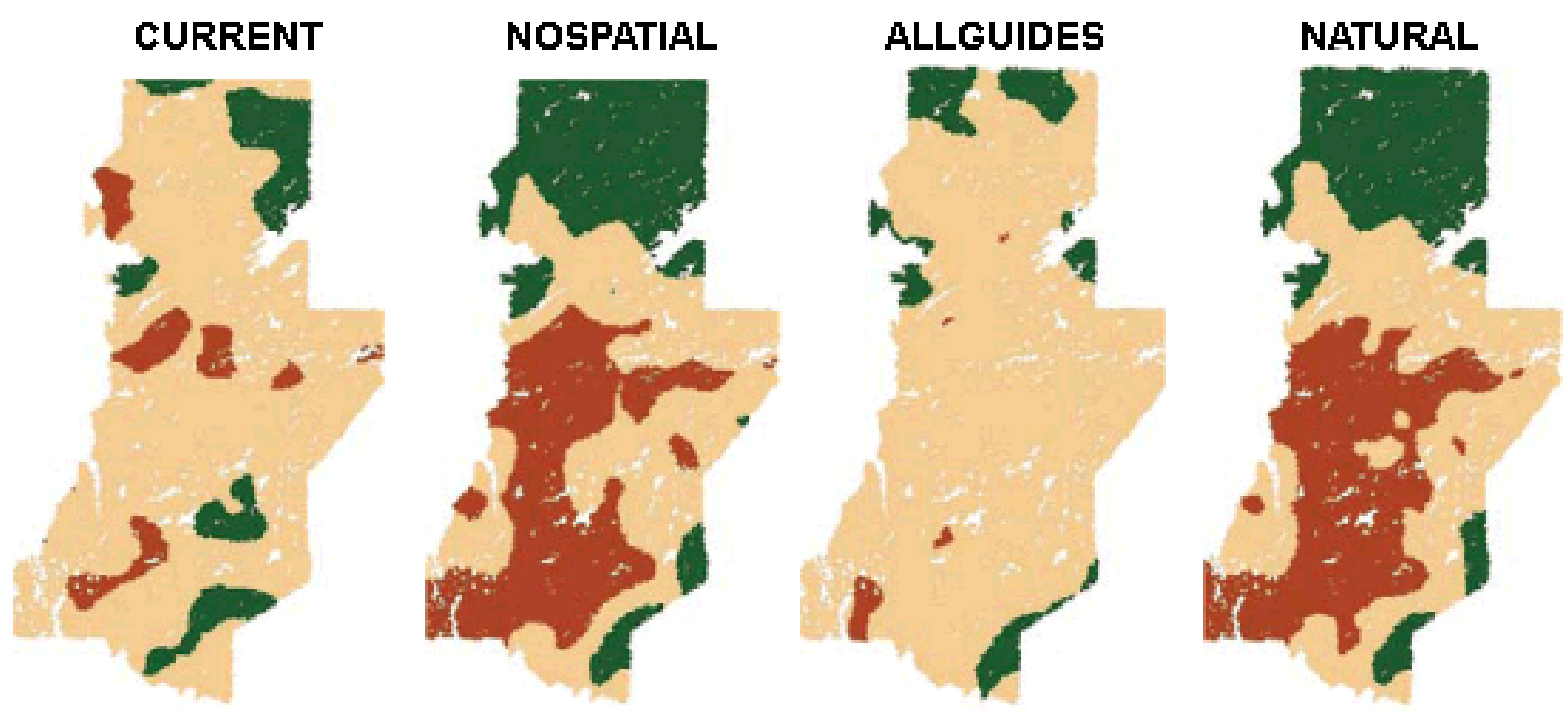

\section{INTACT}

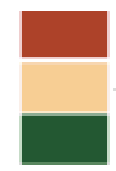

$0-0.234$

$0.235-0.763$

$>0.763$

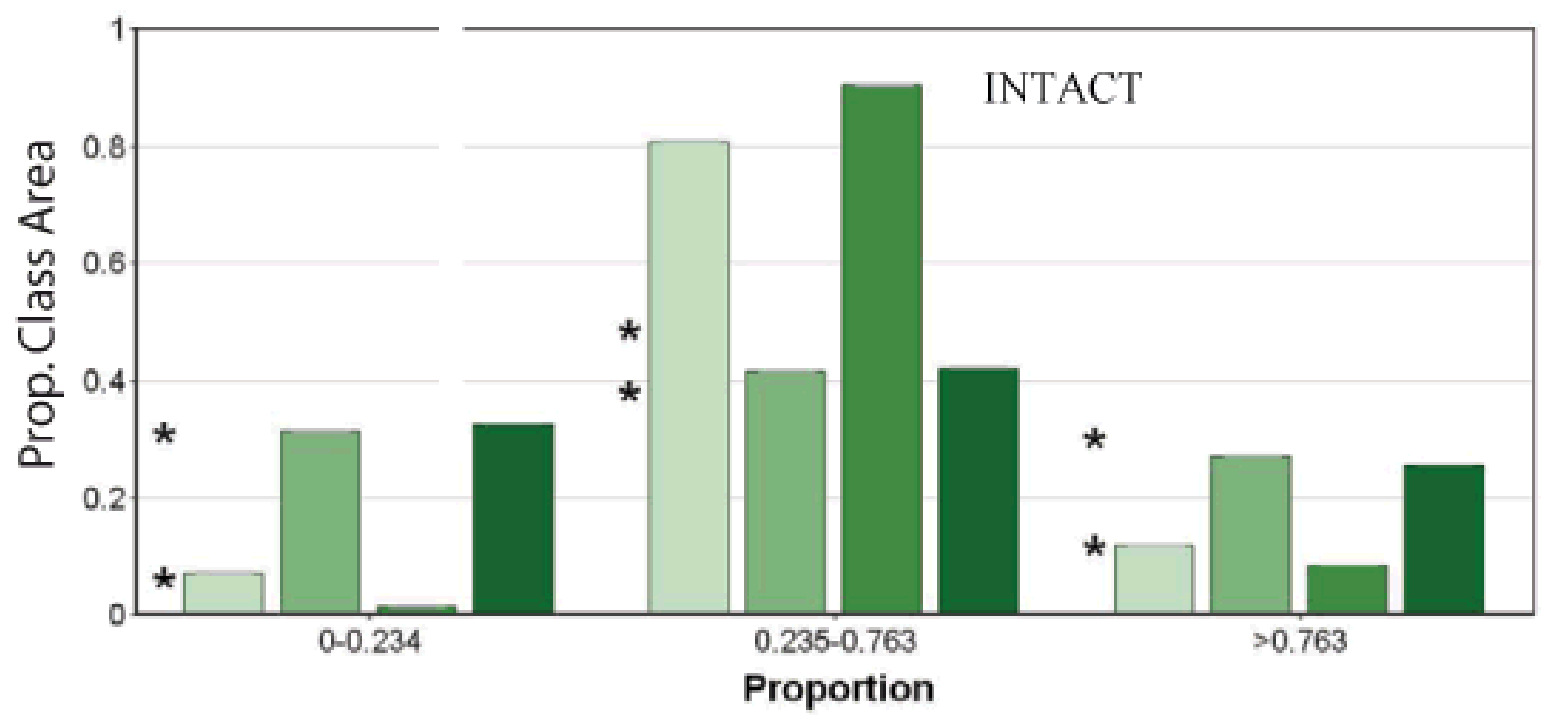

Left to right: CURRENT, NOSPATIAL, ALLGUIDES, NATURAL 
Fig. 10. Spatial pattern signatures for contrast weighted edge density (EDGE) based on Patchworks projections (year 100) of four management scenarios (see Table 2 for definitions). Histograms depict proportion of map-area for low, medium, and high EDGE for each of the four scenarios, and asterisks represent SRNV for EDGE.
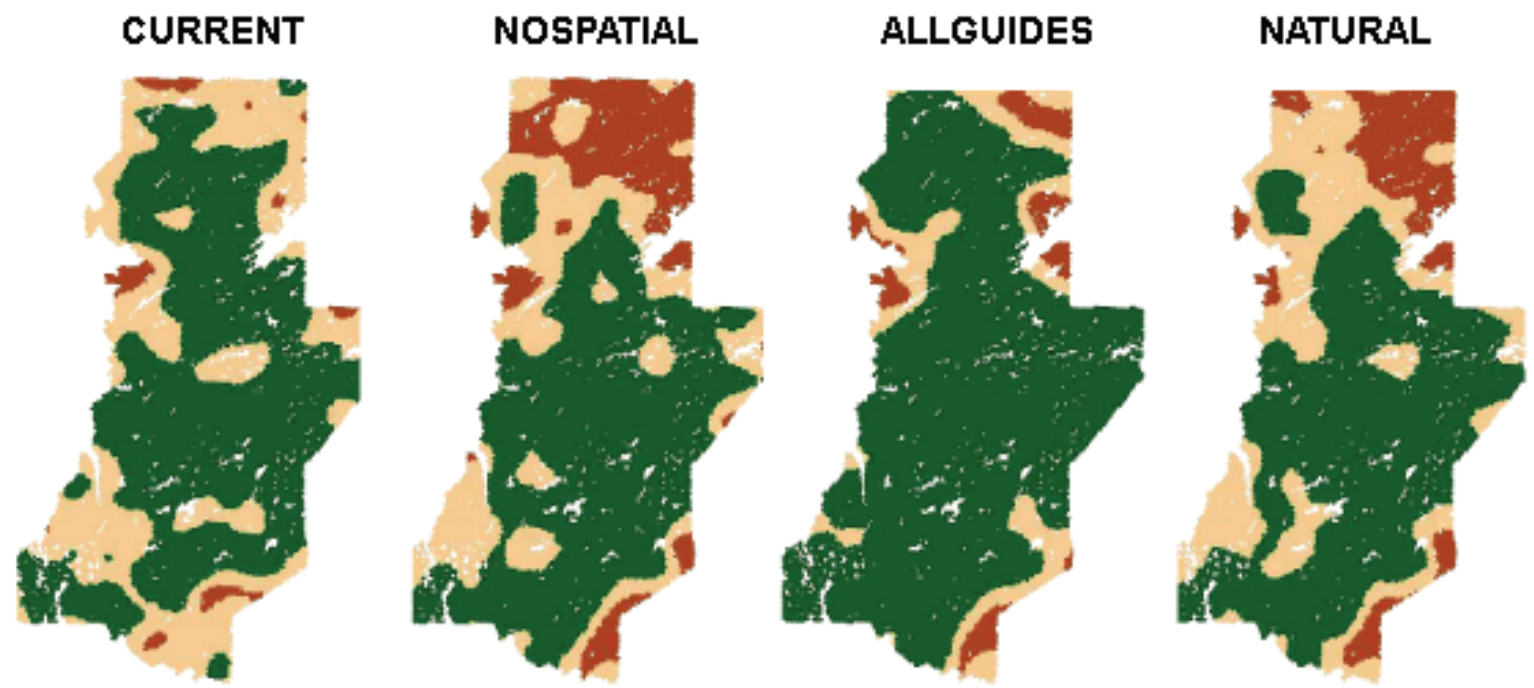

EDGE

(m/ha)
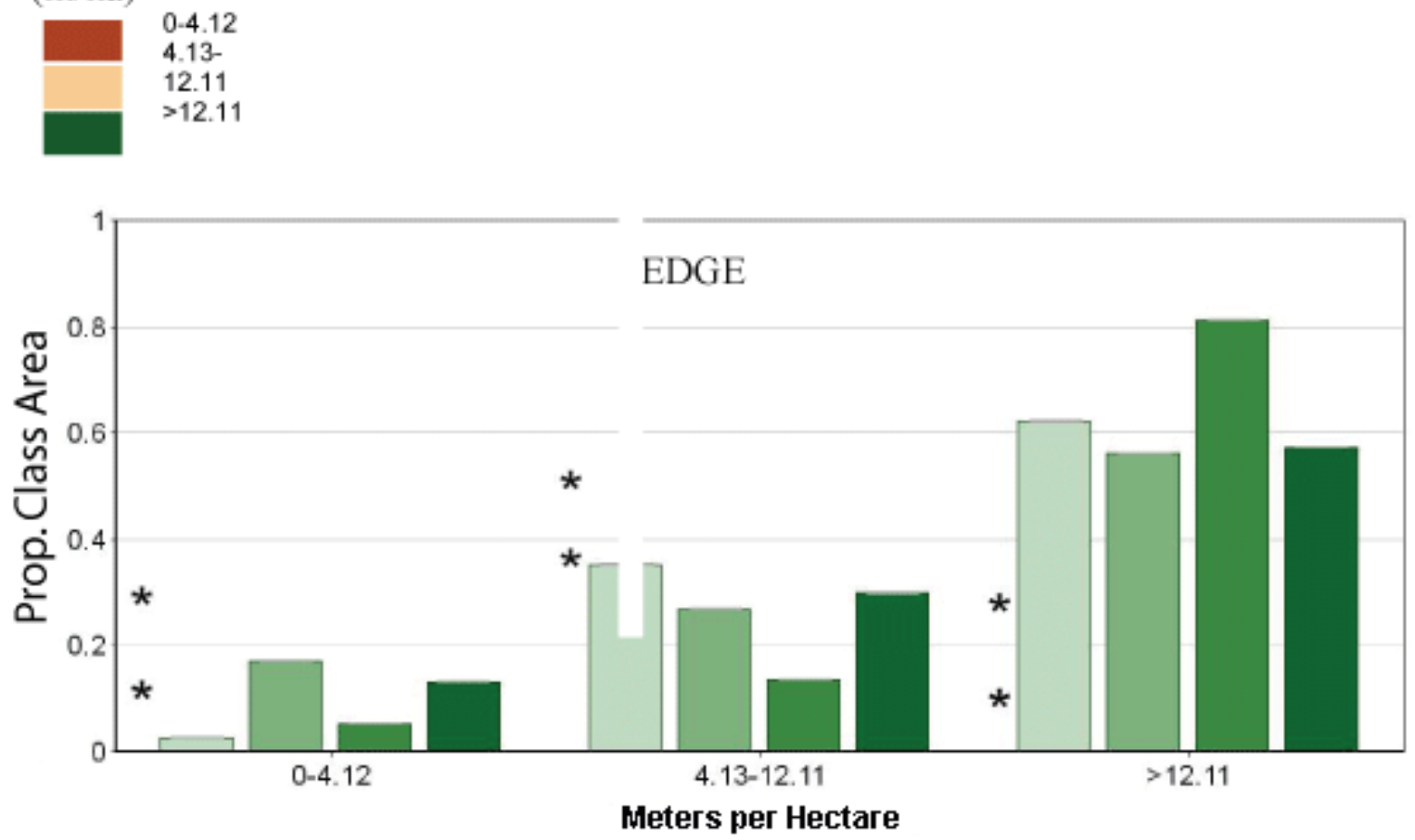

Left to right: CURRENT, NOSPATIAL, ALLGUIDES, NATURAL 
Table 4. Summary of forest response $\dagger$ relative to simulated range of natural variation (SRNV) for modeled variables at year 0 (CURRENT) and at year 100 (NOSPATIAL, ALLGUIDES, and NATURAL).

\begin{tabular}{|c|c|c|c|c|}
\hline \multirow[t]{2}{*}{ Variable } & \multicolumn{4}{|c|}{ Scenario $\neq$} \\
\hline & CURRENT & NOSPATIAL & ALLGUIDES & NATURAL \\
\hline HEIGHT & 1 & -1 & -1 & -1 \\
\hline HARDWOOD & -1 & 1 & 1 & 1 \\
\hline CANOPY & -1 & 1 & 1 & 1 \\
\hline AGE & -1 & 1 & -1 & 1 \\
\hline YOUNG & -1 & -1 & -1 & -1 \\
\hline EDGE & -1 & -1 & -1 & -1 \\
\hline INTACT & -1 & 1 & -1 & 1 \\
\hline Sum & -5 & 1 & -3 & 1 \\
\hline
\end{tabular}

$\dagger$. Response I indicates an increase in the overall level of the variable, relative to SRNV, and D represents a decrease. $M$ indicates the variable is maintained within the bounds of SRNV.

$\$$. Current state of the forest (CURRENT), no spatial guidelines (NOSPATIAL), featured values guidelines (ALLGUIDES), and natural composition targets (NATURAL).

\section{Songbird Habitat}

Through the spatial habitat models, forest structure is translated into probabilities of habitat occupancy, and resulting pattern signatures are interpreted similar to the forest signatures. For Black-and-white Warbler, pattern signatures for year 100 demonstrate more habitat for NOSPATIAL and NATURAL compared with ALLGUIDES, relative to SRNV (Fig. 11). The habitat model for the early seral stage Black-and-white Warbler (Table 3) translates younger forest, a more fragmented mature forest matrix, and a higher percentage of hardwood forest into highly used habitat.

Spatial and temporal patterns in forest structure are influenced by a number of factors, but for the ALLGUIDES scenario, the caribou mosaic and marten cores (Fig. 4) have a pronounced influence, as blocks of forest sequentially become available or unavailable for harvest. For example, the pattern of edge and age over time is influenced by these spatial constraints to harvest, and this is further reflected by the distribution of Winter Wren habitat, which is positively associated with older forest (Fig. 12). The sequential timing of these spatial constraints, however, also forces a more even distribution of harvest over the landscape, and over time. This effect can be seen in the distribution of young forest among the three management scenarios, and the patterns of habitat occupancy for species dependent on younger forest (Fig. 13).

There are clear differences in the temporal patterns for hardwood, intact forest, and Ovenbird habitat among the ALLGUIDES and NATURAL scenarios (Fig. 14). Relative to the NATURAL scenario, the ALLGUIDES shows a big drop in the amount of hardwood forest and the amount of mature intact matrix. In contrast, the NATURAL scenario has 
Fig. 11. Spatial pattern signatures for Black-and-white Warbler (BAWW) based on Patchworks projections (year 100) of four management scenarios (see Table 2 for definitions). Histograms depict proportion of map-area for low vs. high expected habitat occupancy for each of the four scenarios, and asterisks represent SRNV.
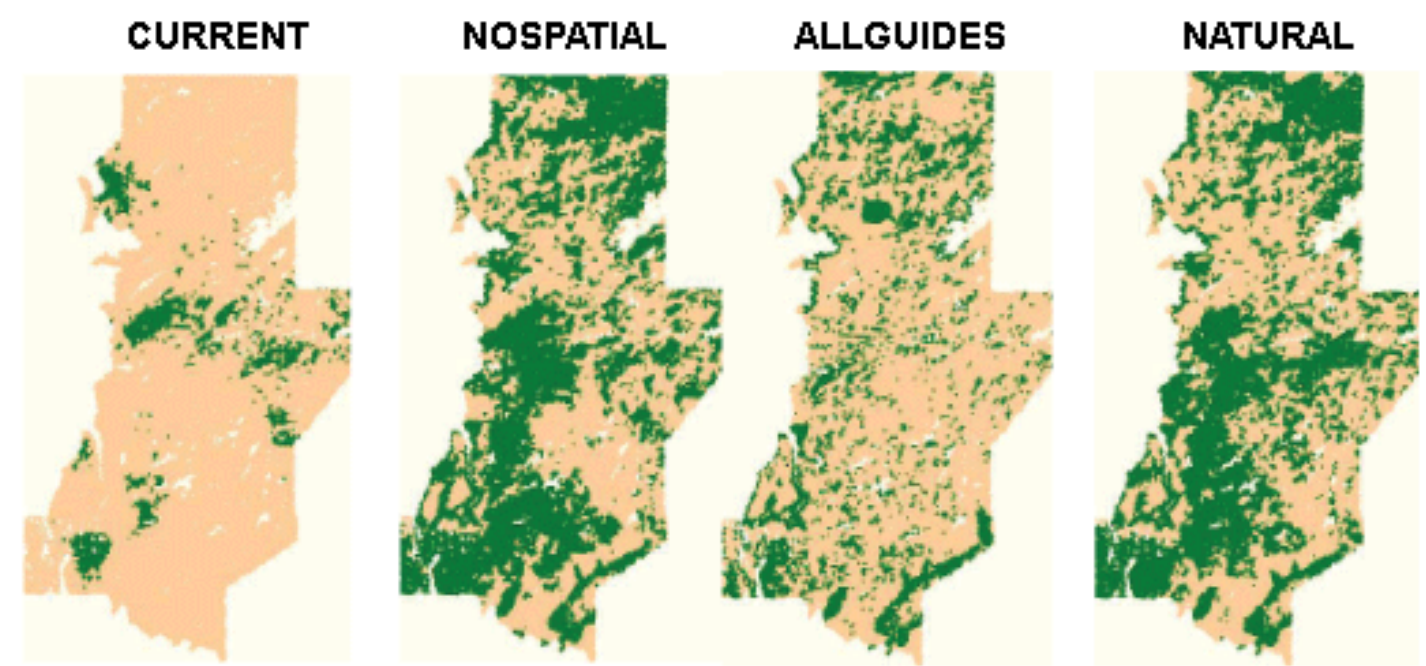

BAWW

Prob. Habitat. Occup.

Low

High

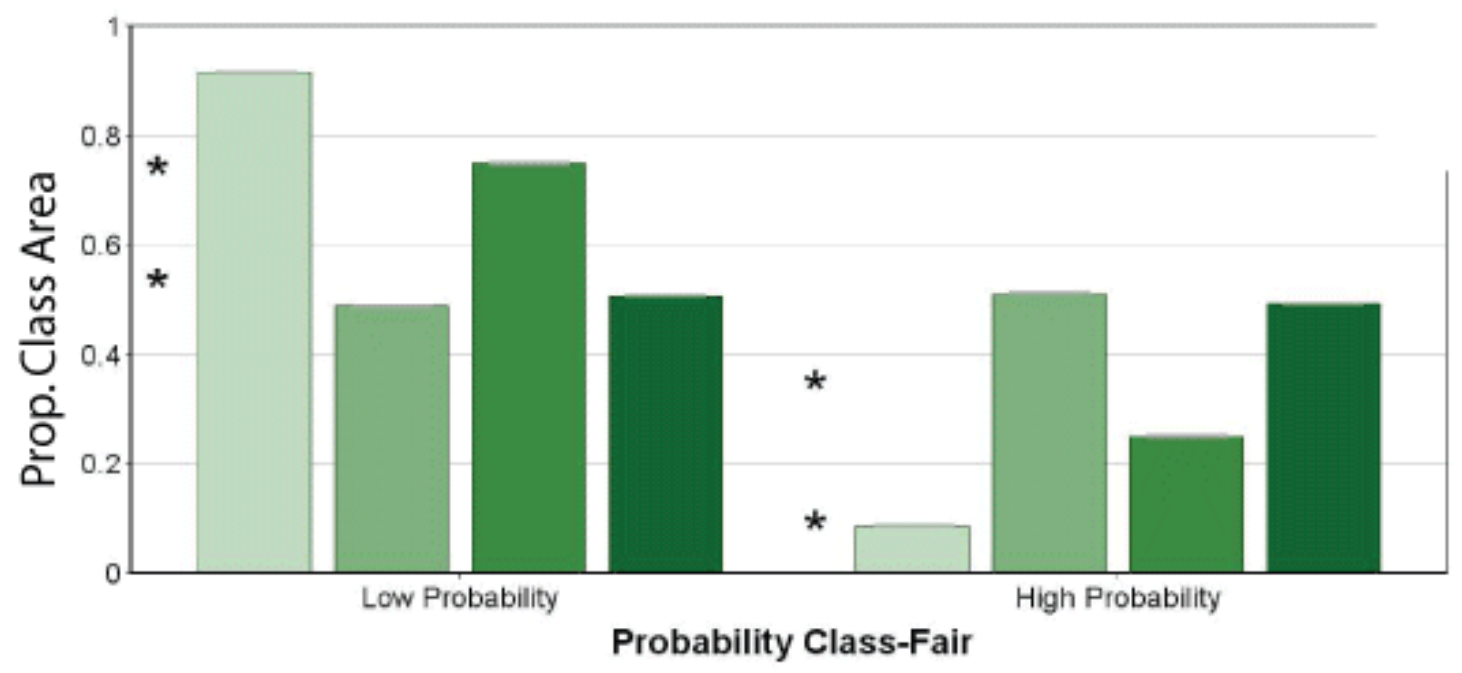

Left to right: CURRENT, NOSPATIAL, ALLGUIDES, NATURAL 
Fig. 12. Change in spatial patterns of landscape edge (EDGE), local age (AGE), and predicted habitat occupancy for Winter Wren, under ALLGUIDES scenario for years 50, 100, and 150.
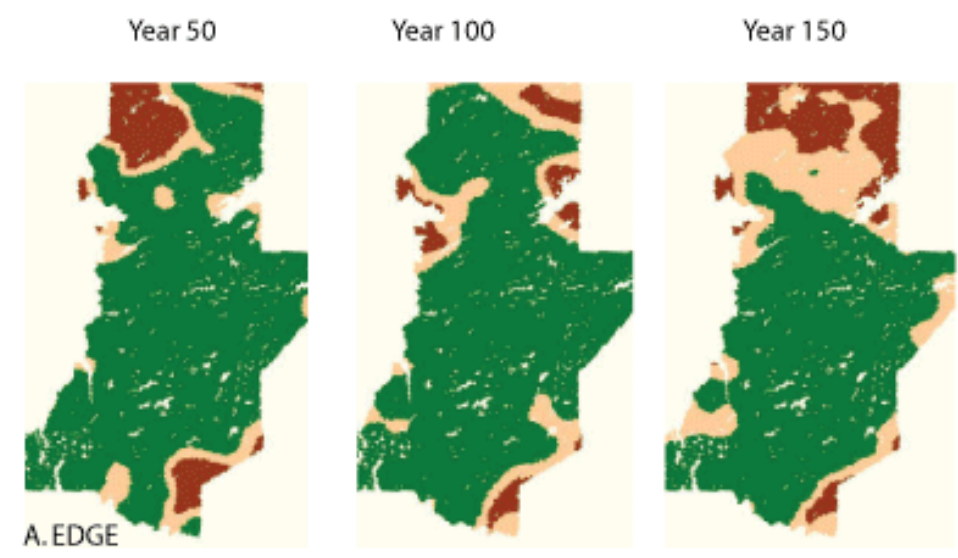

Meters per Hectare
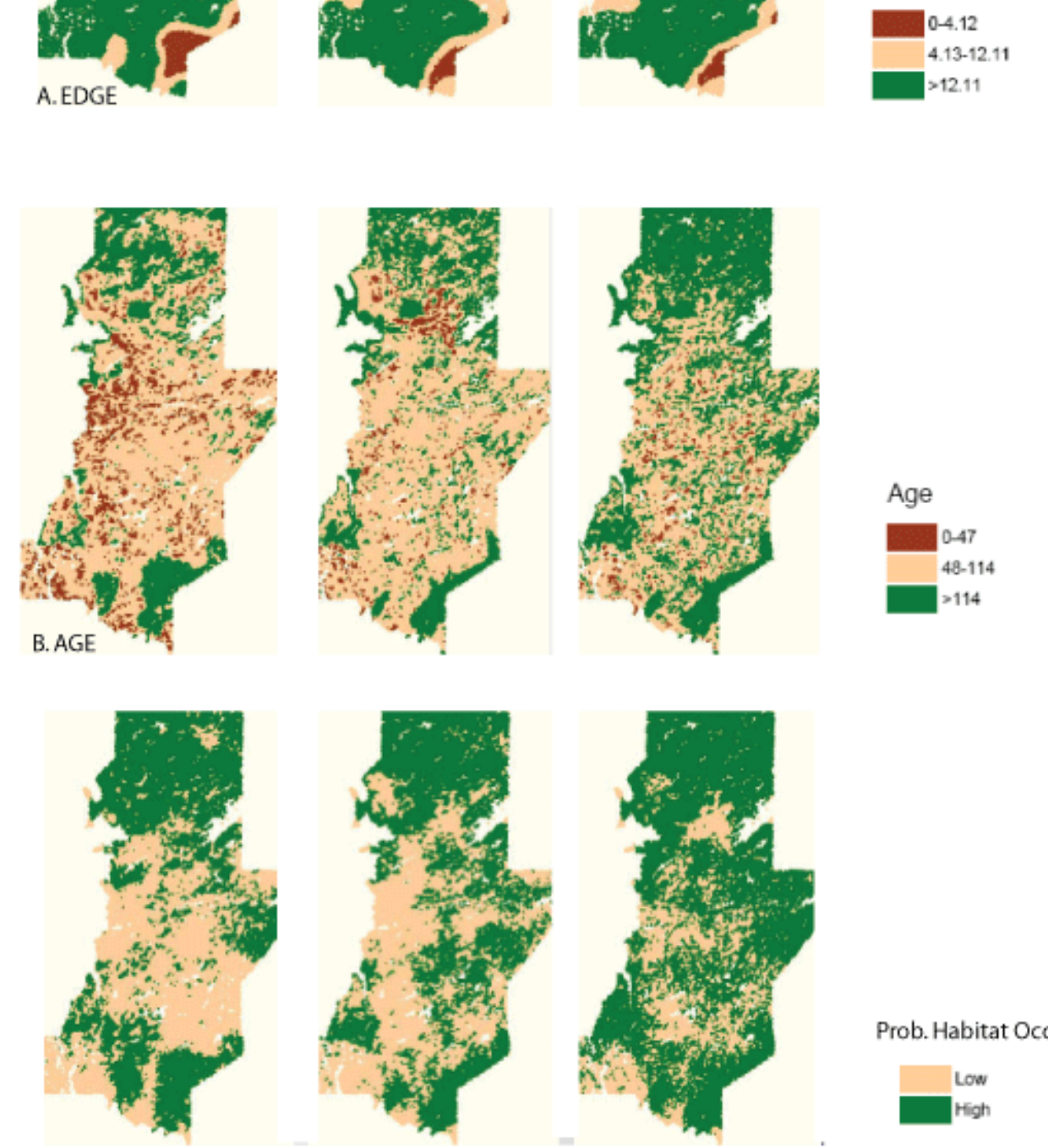

Prob. Habitat Occup.

C.Winter Wren

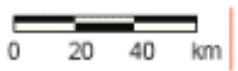


Fig. 13. Change in spatial pattern of young forest (YOUNG) at the local scale, and the probability of habitat occupancy for Common Yellowthroat, under scenarios NOSPATIAL, ALLGUIDES, and NATURAL at year 100.

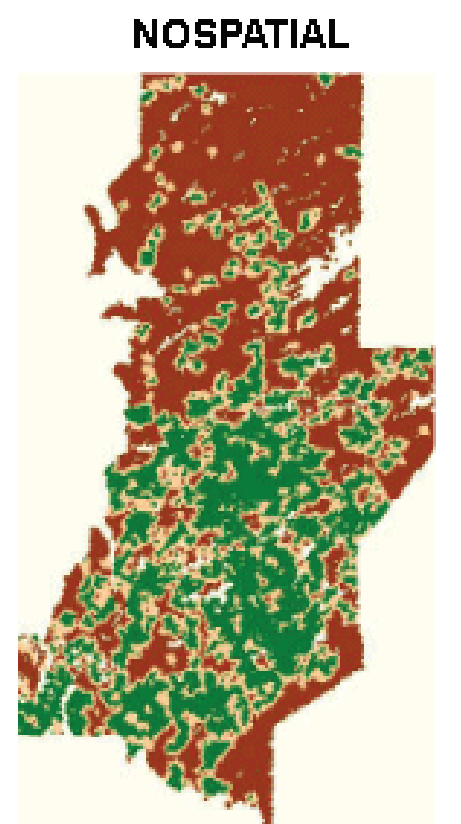

A. YOUNG

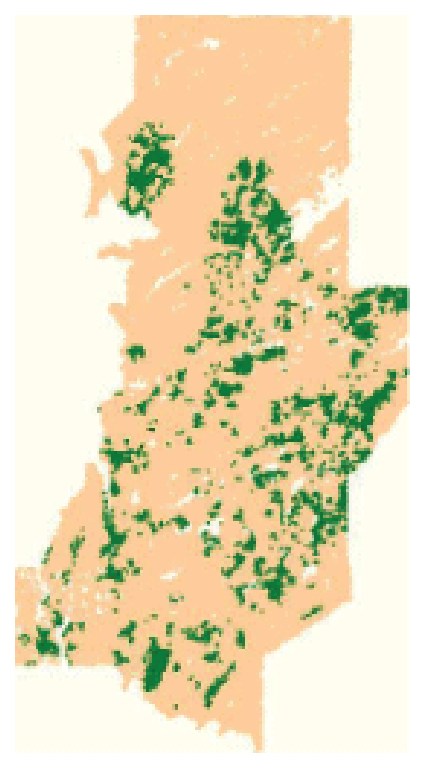

B. Common Yellowthroat
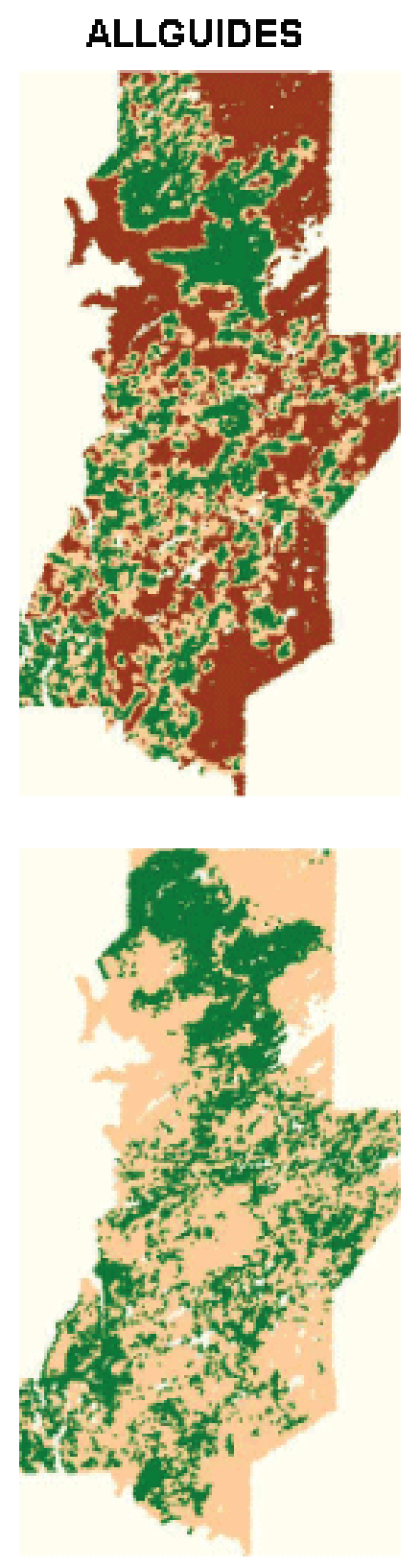

Percent
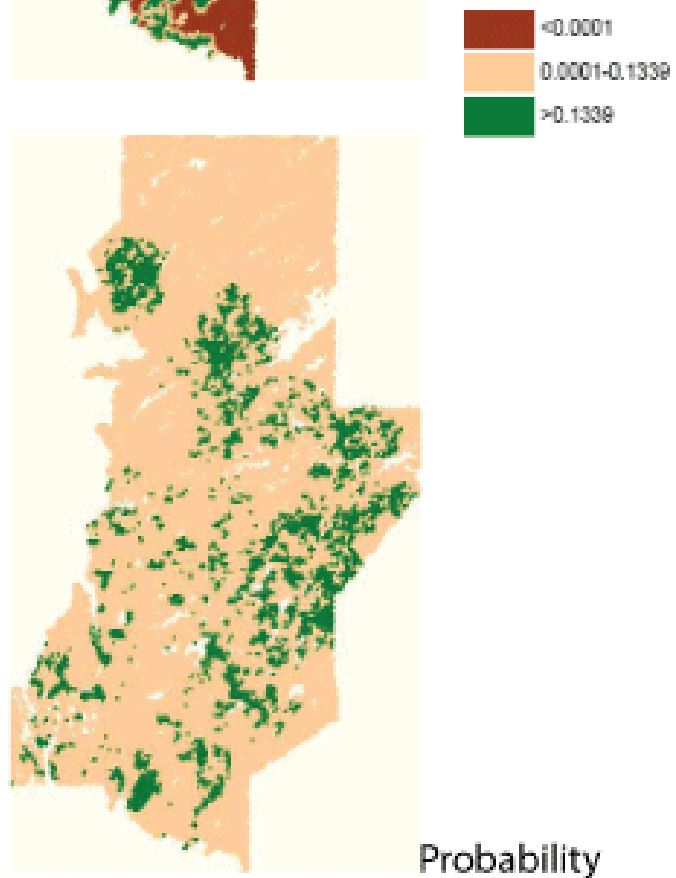

Probability

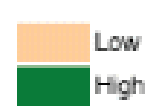

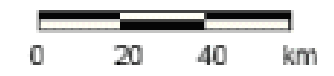


increasing levels of intact forest over time, and this will provide greater amounts of habitat for interior forest matrix species. Ovenbird shows a decline for both scenarios, in part because of the decrease in hardwood, but the decline is markedly less in the NATURAL scenario.

Habitat response was scored slightly different from the forest variable scoring. Where habitat levels decreased below SRNV, the scenario was given a -1 score, but where habitat levels increased above SRNV, the scenario was penalized by a lower value of -0.5 . Where habitat was maintained within SRNV, the scenario was scored 1 (Table 5). In addition, the scoring of scenarios was weighted by the accuracy (ROC value) of the habitat model, so models with high discrimination contributed more to the overall score (Table 5).

Overall, at year 100, habitat levels were maintained within the range of SRNV for six species under NOSPATIAL and NATURAL, whereas only three species were maintained under ALLGUIDES (Table 5). Of the species that prefer lower levels of edge (Bay-breasted Warbler, Blackburnian Warbler, Brown Creeper, Ovenbird, Red-breasted Nuthatch), only Blackburnian Warbler was maintained or increased (relative to SRNV) under the three management scenarios. Five species increased (relative to SRNV) for the ALLGUIDES scenario (Alder Flycatcher, Blackburnian Warbler, Chestnutsided Warbler, Red-eyed Vireo, and White-throated Sparrow), and four of these are associated with either younger forest or higher levels of local disturbance. In terms of overall score, the CURRENT scenario performed just slightly better than the NOSPATIAL or NATURAL scenario, and the ALLGUIDES had a substantially lower score (Table 5). Maps and histograms for all habitat model prediction (ALLGUIDES and NATURAL) scenarios, over years 0, 10, 20, 50, 100, and 150, are given in Appendices 3 and 4.

\section{DISCUSSION}

The distribution of natural wildfires is contagious, resulting in landscapes with clustered areas of high edge separated by large areas with low edge (Rowe and Scotter 1973). It is not surprising, then, that a community of species as diverse as the forest songbirds will exhibit a variety of species-specific responses to edge (Wedeles and Donnelly 2004, Parker et al. 2005, Schieck and Song 2006).
Maintaining the assemblage of forest songbirds, as represented by the focal species group, requires maintenance of habitat conditions that favor hardwood vs. softwood species, old forest vs. young forest species, and edge-loving vs. edge-avoiding species. In this study, the focus of assessing resilience was from a community perspective, and this was achieved by selecting a focal group of species representing a broad range of habitat needs (Rempel 2007). Evaluating forest management policies and practices in terms of this complex assemblage is almost impossible without the use of spatial habitat models that can translate alternative forest configurations into probabilities of habitat occupancy for individual species, over space and time.

Creating the complex arrangement of habitat conditions to support the songbird community requires an understanding of how the distribution and abundance of habitat components relate to the distribution and abundance of the individual focal species. The spatially explicit, multiple-scale habitat models applied here help achieve this understanding, and when applied to forest harvest and succession models, provide the facility to project the expected outcomes of alternative forest harvesting strategies that alter landscape pattern. Interpreting the relative success of the scenarios in terms of conservation management objectives is assisted by positioning these projections in the context of natural disturbance processes (i.e., SRNV).

In our assessment of the three management scenarios, some interesting perspectives emerged. It appears that the greater the number of valuespecific landscape-scale rules that are in place (e.g., the ALLGUIDES scenario), the less similar the resulting landscape is to that expected under SRNV. Rules that dictate the creation of the artificial patterns, such as shoreline forest reserves (fish habitat guidelines) and dispersed block cuts (moose guidelines) force the arrangement of mature forest into linear strips and isolated patches. Therefore, it is not surprising that this deviation from natural patterns has predicted negative consequences on biodiversity objectives, especially when a full array of disturbance-preferring and disturbance-avoiding species is considered. In contrast to the scenario that does not prescribe any landscape-scale direction (NOSPATIAL), ALLGUIDES again performs poorly for some species. This finding is not new. For example, Loehle et al. $(2002,2006)$ found in 
Fig. 14. Changes in hardwood (HARDWOOD), intact forest matrix (INTACT), and Ovenbird habitat, for ALLGUIDES and NATURAL scenarios, over years 0, 10, 20, 50, 100, and 150 (light to dark green bars).

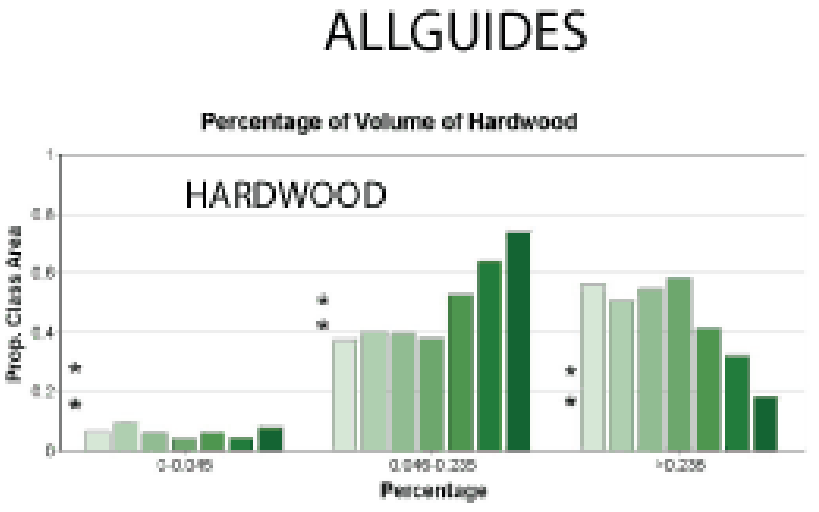

NATURAL
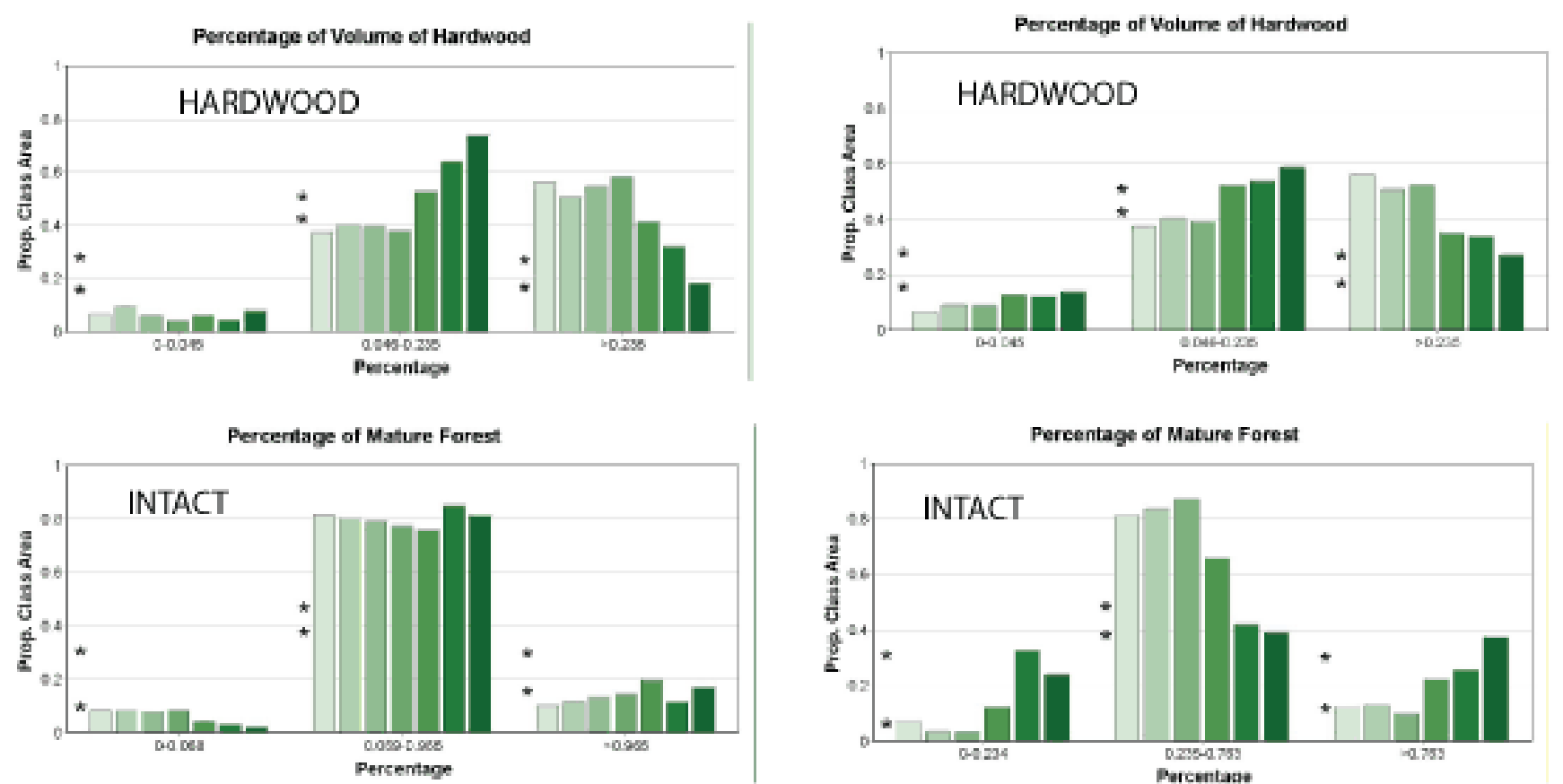

High Vs Low Probability: OVEN Habitat Occupancy
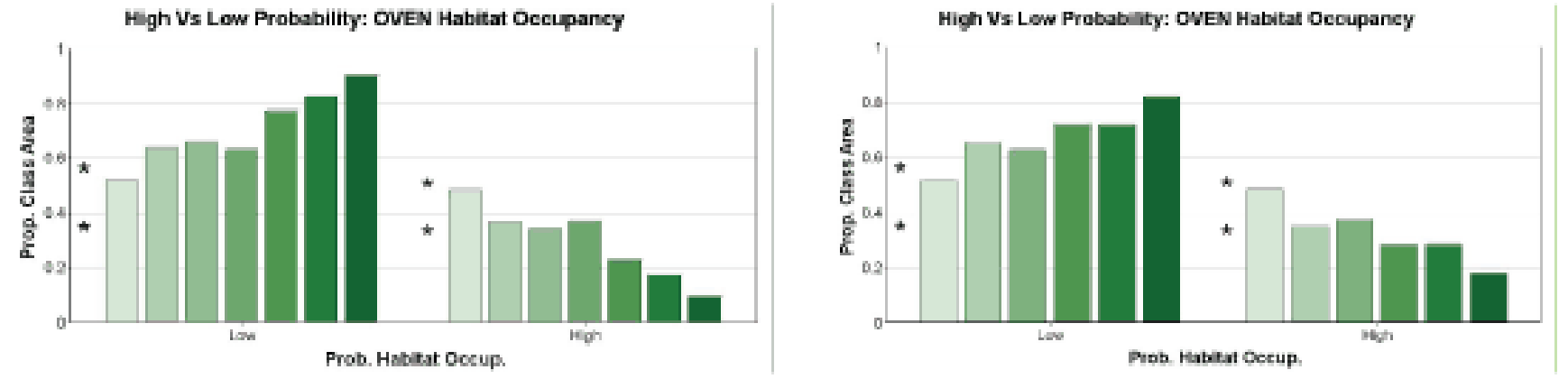

their spatial assessment of forestry guidelines that block-size restriction and riparian buffer strips were both expensive and of little value to songbirds. If the principal objective is to emulate natural patterns (OMNR 2002), then the current set of spatial guidelines used in Ontario performs poorly. This is almost certainly related to the large number of small clearcuts and linear buffer strips that are spread evenly across the landscape.
The ALLGUIDES scenario, however, also explicitly defines broad spatial and temporal patterns based on timings for availability with caribou blocks and marten core area reserves (Fig. 4), and the ALLGUIDES includes non-spatial oldgrowth targets and spatial pattern objectives based on the Natural Pattern Emulation Guidelines (OMNR 2002). This scenario results in positive aspects for biodiversity conservation, including the maintenance of relatively large patches of mature 
Table 5. Summary of habitat response $\dagger$ relative to simulated range of natural variation (SRNV) for modeled variables at year 0 (CURRENT) and at year 100 (NOSPATIAL, ALLGUIDES, and NATURAL).

\begin{tabular}{|c|c|c|c|c|c|}
\hline \multirow[t]{2}{*}{ Species } & \multicolumn{4}{|c|}{ Scenario $\ddagger$} & \multirow[t]{2}{*}{ ROC } \\
\hline & CURRENT & NOSPATIAL & ALLGUIDES & NATURAL & \\
\hline Alder Flycatcher & 1 & 1 & -0.5 & 1 & 0.770 \\
\hline $\begin{array}{l}\text { Black-and-white } \\
\text { Warbler }\end{array}$ & -1 & -0.5 & 1 & -0.5 & 0.678 \\
\hline Bay-breasted Warbler & -1 & -1 & -1 & -1 & 0.725 \\
\hline Blackburnian Warbler & -0.5 & 1 & -0.5 & 1 & 0.668 \\
\hline Brown Creeper & -0.5 & -1 & -1 & -1 & 0.728 \\
\hline $\begin{array}{l}\text { Common Yellowt- } \\
\text { hroat }\end{array}$ & -1 & -1 & -1 & -1 & 0.833 \\
\hline $\begin{array}{l}\text { Chestnut-sided } \\
\text { Warbler }\end{array}$ & -0.5 & 1 & -0.5 & 1 & 0.757 \\
\hline Least Flycatcher & 1 & 1 & 1 & 1 & 0.687 \\
\hline Ovenbird & 1 & -1 & -1 & -1 & 0.796 \\
\hline $\begin{array}{l}\text { Red-breasted Nuth- } \\
\text { atch }\end{array}$ & 1 & -1 & -1 & -1 & 0.708 \\
\hline Red-eyed Vireo & -0.5 & -0.5 & -0.5 & -0.5 & 0.803 \\
\hline Winter Wren & 1 & 1 & 1 & 1 & 0.809 \\
\hline $\begin{array}{l}\text { White-throated } \\
\text { Sparrow }\end{array}$ & 1 & 1 & -0.5 & 1 & 0.749 \\
\hline Sum & 1 & 0 & -4.5 & 0 & \\
\hline Weighted Sum $\S$ & 0.80 & -0.09 & -3.49 & -0.09 & \\
\hline
\end{tabular}

$\dagger$. Response -.05 indicates an increase in the overall level of the variable, relative to SRNV, and -1 represents a decrease. 1 indicates the variable is maintained within the bounds of SRNV.

\$. Current state of the forest (CURRENT), no spatial guidelines (NOSPATIAL), featured values guidelines (ALLGUIDES), and natural composition targets (NATURAL).

$\S$. Sum weighted by ROC model accuracy. 
forest throughout the forest management unit, over time, and is reflected in the patterns of predicted habitat occupancy for Winter Wren (Fig. 12). As well, it may be necessary to deviate from natural patterns to achieve social objectives. Ontario's Crown Forest Sustainability Act directs forest management to emulate natural disturbance landscape patterns, within the limits of silviculture, while minimizing the negative effects on a range of social, economic, and ecological values (Government of Ontario 1994). For example, linear strips of forest along canoe routes provide excellent wilderness experience conditions, so, from a human-habitat perspective, it is important to maintain at least some of these linear strips of old forest. In contrast, maintaining artificially high levels of older coniferous forest in narrow strips along such water bodies reduces the suitability for beaver habitat (Martell et al. 2006). This may have cascading biodiversity and ecosystem resilience consequences, especially for waterfowl populations occupying active beaver ponds, and other species requiring the wet meadows created by abandoned ponds. The final selection of policy options for management guides or the preferred management option for forest management plans will depend on a number of factors. The role of spatial habitat and forest simulation models is simply to help inform decision making, and to help place management objectives and decisions in a broader context of ecosystem resilience and biodiversity conservation.

Composition target objectives (e.g., retained abundance of mature mixedwood) for the NATURAL scenario were based on the results from initial runs of the BFOLDS, so it is by design that the NATURAL scenario more closely resembles the SRNV. Thus, BFOLDS-based SRNV provides both a baseline context for evaluating changes in forest structure and habitat occupancy patterns, and the composition targets for the natural pattern scenario in Patchworks. This begs the question of accuracy and bias of the disturbance simulator and succession curves. The BFOLDS is based on published research findings for component processes, such as stand succession and rates of fire spread (Perera et al. 2004), and simulation models are the only reasonable way we can estimate the range of conditions expected under a pristine natural disturbance regime. Theoretical comparisons have shown that BFOLDS fire-spread rates, fire intensities, and sizes of fire events are comparable to theoretical predictions under most weather conditions (Cui and Perera, in review). The predictions of generally lower edge at the ecoregional level under a natural disturbance regime make intuitive sense, and are supported by observations of regions in the far north of Ontario, where fire suppression does not occur.

There are clear limitations and qualifications to projecting 100 or even 5 years into the future, however, several key spatial/temporal policy options in the Nipigon Forest (e.g., the caribou mosaic deferment blocks) require simulation of at least 100 years, as some blocks only become available at year 80 (Fig. 4). The spatial harvest model for the Nipigon was based in part on transportation networks and location of mills, but two paper mills closed and one plywood mill burned within 1 year of running the model. Thus, even a simulation period of only 5 years is too long in terms of model realism. Climate change, political trends, and economic volatility will certainly add additional uncertainty, and a host of environmental factors (including windthrow, wildfire, and insect outbreaks) will ultimately invalidate any specific predictions. The models are based on the simplifying assumption that certain environmental, political, and economic factors are held constant, whereas other exploratory factors are varied. The models are meant to provide strategic and general insights within a framework of operational realism, but the application of the models (as used in this study) cannot accurately predict exactly what will happen on any given piece of ground at any future given time. In contrast, it might be useful to vary climatic factors, while holding a few management options constant, and this will be the focus of future research.

The meta-modeling approach used in this study introduces several key elements of model uncertainty. Among the natural disturbance simulation, spatial habitat, harvest schedule, stand succession, and canopy closure models, a key model in this study is the spatial habitat model. The spatial habitat models are based on data collected using a mensurative design, where patterns of association are derived from empirical songbird observations using existing combinations of factors in the field. The mensurative approach permits extensive sampling over large areas, and this is important to reduce the influence of spatial-autocorrelation with landscape-scale variables, but compared with a controlled experimental design, the mensurative approach reduces the ability to statistically control for environmental variability. As well, the empirical 
models do not demonstrate cause and effect or estimate relative fitness within habitat types - they only establish patterns of association - and in many cases, it is still unknown why a species would select areas of high edge. Perhaps these areas have higher densities of food items such as flying insects or seeds (Parker et al. 2005), but the explanations are still generally unknown and require further research.

Focal species were selected to represent the entire forest songbird community, and the species selected for the focal group essentially represent the extreme conditions within the community niche-space. For example, species with the strongest need for an intact mature forest matrix, the greatest need for high edge, or strongly selecting closed hardwood, were included in the focal group. Modeling habitat conditions for this focal group provides solid information to help forest managers develop and evaluate plans that will create a sufficient range and diversity of forest conditions to support the songbird community. However, the variables considered in this study should be considered coarse-filter variables, and thus, the spatial habitat models simply describe the general framework of forest structure and pattern required by the focal species. Scenario evaluation is partly dependent upon the accuracy of the habitat models, so models should be continuously tested and updated in an adaptive management context, with the goal of better understanding cause-effect relationships.

The scale at which variables were measured was partly arbitrary, in that the 50-ha scale was selected for local-scale variables because it corresponds to the extent of area surveyed by a cluster of listening point stations, and the 5000-ha scale was selected for landscape-scale effects because this corresponds to the maximum distance of spatial autocorrelation generally found between listening stations, and is in the approximate size of many stand-structuring wildfire events. For a community-level study, it was useful to standardize the scale of measurement to facilitate comparisons among species. However, further exploration of the inter-correlation of variables measured at differing scales, and the correlation of these variables with habitat occupancy may lead to more precise habitat models.

\section{CONCLUSION}

The results of this study support the adoption of boreal forest management strategies that create clustered areas of high edge separated by large areas of intact forest matrix. It is the combination of these conditions that will create the diversity of forest patterns necessary to support the full range of boreal forest songbirds. The analysis also supports using compositional targets based on natural disturbance simulations. At the community level, some songbird species are resilient to edge, and others less so. Only by creating the combination of conditions will the coarse-filter habitat needs of the entire community be met. Spatially explicit, quantitative habitat models developed for a focal set of songbird species describe the target levels and range of variability in forest conditions required, as a minimum, to support the full complement of boreal forest songbird species. The simulated range of natural variability helps define the temporal variability that should be expected for both forest variables and associated habitat occupancy patterns. The approach of strategically modeling long-term patterns, but using realistic operational constraints, adds both validity and complexity to model interpretation.

Responses to this article can be read online at: http://www.ace-eco.org/vol2/iss 1/art5/responses/

\section{Acknowledgments:}

This project was support by numerous OMNR and ENGO members of the Landscape Guide Development Team and Landscape Guide Boreal Science Team. In addition, Heather Tumber (Spatial Planning Systems) programmed and ran most of the Patchworks scenario scripts, Julie Elliott (OMNR) programmed and ran most of the LSL habitat analysis scripts, and Kevin Ride (OMNR) helped refine many of the forest succession pathways. Dave Euler (Birch Point Enterprises), Ian Thompson (Natural Resources Canada - Canadian Forest Service), and Kandyd Szuba (Domtar Inc.) provided useful advice and criticisms throughout the project. The editor and anonymous reviewers provided very helpful advice. 


\section{LITERATURE CITED}

Arthaud, G. J., and D. W. Rose. 1996. A methodology for estimating production possibility frontiers for wildlife habitat and timber value at the landscape level. Canadian Journal of Forest Research 26:2191-2200.

Baskent, E. Z., and G. A. Jordan. 2002. Forest landscape management modeling using simulated annealing. Forest Ecology and Management 165:29-45.

Baskent, E. Z., and S. Keles. 2005. Spatial forest planning: a review. Ecological Modelling 188:145173.

Bunnell, F. L. 1995. Forest-dwelling vertebrate faunas and natural fire regimes in British Columbia: patterns and implications for conservation. Conservation Biology 9:636-644.

Calkin, D. E., C. A. Montgomery, N. H. Schumaker, S. Polasky, J. L. Arthur, and D. J. Nalle. 2002. Developing a production possibility set of wildlife species persistence and timber harvest value. Canadian Journal of Forest Research 32:1329-1342.

Elkie, P., A. Rudy, and M. Gluck. 2004. Forest attribute look-up tables. Internal report. Ontario Ministry of Natural Resources, Thunder Bay, Ontario, Canada.

Fall, A., and J. Fall. 2001. A domain-specific language for models of landscape dynamics. Ecological Modelling 141:1-18.

Fall, A., M. J. Fortin, D. D. Kneeshaw, S. H. Yamasaki, C. Messier, L. Bouthillier, and C. Smyth. 2004. Consequences of various landscapescale ecosystem management strategies and fire cycles on age-class structure and harvest in boreal forests. Canadian Journal of Forest Research 34:310-322.

Government of Ontario. 1994. Crown Forest Sustainability Act. Queen's Printer for Ontario, Toronto, Ontario, Canada.

Hannon, S. J., and C. McCallum. 2004. Using the focal species approach for conserving biodiversity in landscapes managed for forestry. Sustainable Forest Management Network, Edmonton, AB. 47 p.
Hills, G. A. 1961. The ecological basis for land-use planning. Research Report No. 46. Ontario Department of Lands and Forests, Toronto, Ontario, Canada.

Hunter, M. L. Jr. 1993. Natural fire regimes as spatial models for managing boreal forests. Biological Conservation 65:115-120.

Johnson, C. J., D. R. Seip, and M. S. Boyce. 2004. A quantitative approach to conservation planning: using resource selection functions to map the distribution of mountain caribou at multiple spatial scales. Journal of Applied Ecology 41:238-251.

Kushneriuk, R. S., and R. S. Rempel. 2004. Landscape scripting language. Centre for Northern Forest Ecosystem Research; Ontario Ministry of Natural Resources, Thunder Bay, Ontario, Canada.

Liu, G. L., J. D. Nelson, and C. W. Wardman. 2000. A target-oriented approach to forest ecosystem design-changing the rules of forest planning. Ecological Modelling 127:269-281.

Loehle, C., J. G. MacCracken, D. Runde, and L. Hicks. 2002. Forest management at landscape scales-solving the problems. Journal of Forestry 100:25-33.

Loehle, C., P. van Deusen, T. B. Wigley, M. S. Mitchell, S. H. Rutzmoser, J. Aggett, J. A. Beebe, and M. L. Smith. 2006. A method for landscape analysis of forestry guidelines using bird habitat models and the Habplan harvest scheduler. Forest Ecology and Management 232:56-67.

Lockwood, C., and T. Moore. 1993. Harvest scheduling with spatial constraints: a simulated annealing approach. Canadian Journal of Forest Research 23:467-478.

Martell, K. A., A. L. Foote, and S. G. Cumming. 2006. Riparian disturbance due to beavers (Castor canadensis) in Alberta's boreal mixedwood forests: implications for forest management. Ecoscience 13:164-171.

Mitchell, M. S., R. A. Lancia, and J. A. Gerwin. 2001. Using landscape-level data to predict the distribution of birds on a managed forest: effects of scale. Ecological Applications 11:1692-1708.

Mitchell, M. S., S. H. Rutzmoser, T. B. Wigley, C. 
Loehle, J. A. Gerwin, P. D. Keyser, R. A. Lancia, R. W. Perry, C. J. Reynolds, R. E. Thill, R. Weih, D. White, and P. B. Wood. 2006. Relationships between avian richness and landscape structure at multiple scales using multiple landscapes. Forest Ecology and Management 221:155-169.

Ontario Ministry of Natural Resources (OMNR). 1988a. Timber management guidelines for the protection of fish habitat. Queen's Printer for Ontario, Toronto, Ontario, Canada.

1988b. Timber management guidelines for the provision of moose habitat. Queen's Printer for Ontario, Toronto, Ontario, Canada.

- 1996. Forest management guidelines for the provision of marten habitat. Queen's Printer for Ontario, Toronto, Ontario, Canada.

-2002. Nature's way-the guide for natural disturbance pattern emulation for forest harvesting. Queen's Printer for Ontario, Toronto, Ontario, Canada.

Parker, T. H., B. M. Stansberry, C. D. Becker, and P. S. Gipson. 2005. Edge and area effects on the occurrence of migrant forest songbirds. Conservation Biology 19:1157-1167.

Perera A. H., D. G. Yemshanov, F. Schnekenburger, D. J. B. Baldwin, D. Boychuk, and K. Weaver. 2004. Spatial simulation of broadscale fire regimes as a tool for emulating natural forest disturbance. Pages 112-122 in A. H. Perera, L. J. Buse, and M. G. Weber, editors. Emulating natural forest landscape disturbances: concepts and applications. Columbia University Press, New York, New York, USA.

Racey, G., A. Harris, L. Gerrish, E. Armstrong, J. McNicol, and J. Baker. 1999. Forest management guidelines for the conservation of woodland caribou: a landscape approach. MS draft. Ontario Ministry of Natural Resources, Thunder Bay, Ontario, Canada.

Rempel, R. S. 2007. Selecting species for biodiversity conservation assessment: an analysis of songbird response to forest cover amount and configuration. Avian Conservation and Ecology Écologie et conservation des oiseaux, in press.

Rempel, R. S., and C. K. Kaufmann. 2003. Spatial modeling of harvest constraints on wood supply versus wildlife habitat objectives. Environmental Management 32:334-347.

Rempel, R. S., D. W. Andison, and S. J. Hannon. 2004. Guiding principles for developing an indicator and monitoring framework. The Forestry Chronicle 80:82-90.

Rempel, R. S., M. Donnelly, L. van Damme, M. Gluck, R. Kushneriuk, and T. Moore. 2006. Spatial landscape assessments models: a metamodelling framework for biodiversity conservation planning. Pages 161-167 in R. Lafortezza and G. Sanesi, editors. Patterns and processes in forest landscapes, consequences of human management. Proceedings of the $4^{\text {th }}$ Meeting of IUFRO Working Party 8.01.03, 26-29 September 2006, Locorotondo, Bari, Italy.

Rowe, J. S., and G. W. Scotter. 1973. Fire in the boreal forest. Quaternary Research 3:444-464

Schieck, J., and S. J. Song. 2006. Changes in bird communities through succession following fire and harvest in boreal forest of western North America: literature review and meta-analyses. Canadian Journal of Forest Research 36:1299-1318.

van Damme, L., J. S. Russell, F. Doyon, P. N. Duinker, T. Gooding, K. Hirsch, R. Rothwell, and A. Rudy. 2003. The development and application of a decision support system for sustainable forest management on the Boreal Plain. Journal of Environmental Engineering Science 2:S23-S34.

Wedeles, C., and M. Donnelly. 2004. Bird-forestry relationships in Canada: literature review and synthesis of management recommendations. Technical Bulletin No. 892. National Council for Air and Stream Improvement, Inc., Research Triangle Park, North Carolina, USA. 
Appendix 1. Maps and histograms for spatial patterns of all model variables (ALLGUIDES scenario), over years $0,10,20,50,100$, and 150 .

Please click here to download file 'appendix1.pdf'. 
Appendix 2. Maps and histograms for spatial patterns of all model variables (NATURAL scenario), over years $0,10,20,50,100$, and 150 .

Please click here to download file 'appendix2.pdf'. 
Appendix 3. Maps and histograms for spatial patterns of all habitat model predictions (ALLGUIDES scenario), over years $0,10,20,50,100$, and 150 .

\section{Please click here to download file 'appendix3.pdf'.}


Appendix 4. Maps and histograms for spatial patterns of all habitat model predictions (NATURAL scenario), over years $0,10,20,50,100$, and 150 .

Please click here to download file 'appendix4.pdf'. 